\title{
Capital budgeting practices in South Africa: A review
}

\author{
C. Correia \\ College of Accounting, University of Cape Town, \\ Private Bag, Rondebosch 7701, Republic of South Africa \\ Carlos.correia@uct.ac.za
}

Received May 2010

\begin{abstract}
This paper reviews the capital budgeting survey literature in South Africa over the period 1972 to 2008. The survey evidence indicates a significant growth in Discounted Cash Flow (DCF) methods and a fall in the use of other methods. In particular, there has been growth in the use of Net Present Value (NPV). Yet, the Internal Rate of Return (IRR) technique remains the primary method used in practice despite some serious drawbacks. Larger companies are more likely to use DCF methods. There has been a significant growth in the use of sensitivity analysis and scenario analysis. However, there is little use of sophisticated risk analysis tools such as Monte Carlo simulation, and decision trees. Although financial theory predicates the use of risk adjusted discount rates, surveys indicate that the majority of companies use a single firm discount rate. Companies have increasingly used inflation-adjusted cash flows but the process of ranking mutually exclusive projects is not aligned with finance theory. There is limited use of the Modified Internal Rate of Return (MIRR) method and DCF dominant companies do not outperform non-DCF dominant companies. The most important phase of project evaluation is the project definition and cash flow estimation phase and yet research studies have focused mainly on the financial analysis and project selection phase.
\end{abstract}

*To whom all correspondence should be addressed.

\section{Introduction}

In capital budgeting there has been a growing convergence between theory and practice in the USA and other countries such as the UK and Australia. Over the last three decades, there have been numerous surveys of capital budgeting practices in South Africa. The objective of this paper is to provide a review of the capital budgeting survey literature over the period 1972 to 2008 , to analyse trends in capital budgeting practices, analyse the state of the art and identify areas for further research. This paper analyses the use of capital budgeting techniques in South Africa as measured by numerous published surveys and unpublished surveys, and compares the use and trends in capital budgeting practices in relation to financial theory. This study also compares results to overseas surveys. The paper focuses on such aspects as capital budgeting methods, risk analysis, discount rates and specific issues such as the performance of postaudits, the evaluation of the relative performance of DCF dominant firms, the treatment of mutually exclusive investments and the acceptance of more recent finance developments such as real options.

The comparison of surveys over time is subject to limitations in terms of drawing inferences in respect to the capital budgeting practices of firms and the compliance to theory. These relate primarily to the differences in the population from which samples are drawn, response rates, sample sizes and the wording of the questions. Further, the South African surveys were evaluating particular aspects of the capital budgeting process, such as the treatment of inflation and the treatment of risk and uncertainty. However, given these limitations, it is still useful to compare results, and to understand the longer term trends in capital budgeting practices and the adoption and adaptation of firms to developments in theory and economic realities. Further, a survey of current practice is useful in terms of determining the methods in use at particular points in time.

\section{The theory and practice of capital budgeting}

In terms of the theory of capital budgeting, it is generally accepted that firms should employ discounted cash flow (DCF) techniques such as the internal rate of return (IRR) and net present value (NPV) to select and rank capital investment projects. These methods have been traditionally termed sophisticated capital budgeting techniques as they consider the time value of money, future cash flows and project risk. In reality, the theoretically correct method is the NPV technique, that is, project selection should be determined by the project which maximises the NPV of the project's future cash flows. The use of the NPV method in relation to the use of the IRR method is based upon the problems arising from the evaluation of mutually exclusive alternatives, when project sizes differ, when the timing of the project cash flows differ or when the project represents a non-conventional project, that is, a project which has significant positive and negative cash flows over the life of the project. More recently, it has been argued (see, Trigeorgis, 1993; Dixit \& Pindyk, 1995; Copeland \& Keenan, 1998; Copeland \& Antikarov, 2001) that NPV does not account for project flexibility and that the value of real 
options linked with projects should be included in the evaluation of capital projects.

Surveys in South Africa up to 2006 found that the internal rate of return method is the preferred primary method used in practice. The use of NPV in terms of theoretical consistency is based upon the nature of projects, for example, whether the firm is evaluating mutually exclusive projects or whether the type of industry results in project cash flows which experience significant changes of sign over the life of the project.

The continued wide use of naive methods such as the payback method and the accounting rate of return method raise some academic questions. Although there has been a growing trend in terms of the use of discounted cash flow methods, the fact is that these methods continue to be widely used by firms. Yet, the use of payback may be rational in highly uncertain environments, and when firms are subject to capital rationing, and in environments of costly information. The use of the accounting rate of return may be relevant in terms of accounting returns being employed in the performance appraisal of management.

The evidence indicates that although the NPV and IRR methods may be theoretically superior to the naive methods such as payback, it was found that the erroneous application of these methods, for example, in terms not making necessary adjustments for such issues as inflation, taxation, the evaluation of mutually exclusive investments and capital rationing will fundamentally impact upon the perceived usefulness of these methods in practice.

In a number of surveys it was found that the vast majority of firms take into account risk in the capital budgeting process and also make adjustments for inflation. However, a number of firms did not take into account taxation in the capital budgeting analysis. The paper analyses the relative use of sophisticated methods by small firms as compared with larger firms. It found that larger firms make more use of discounted cash flow methods as compared to smaller firms.

The adoption of DCF capital budgeting techniques should result in superior firm performance and the paper finds that in fact the evidence in this regard is inconsistent, with international surveys reporting no evidence of superior performance while the South African survey found evidence that firms that adopted sophisticated capital budgeting techniques did not report superior firm performance.

The paper concludes that perhaps academic research has placed too much emphasis on the selection phase of capital investment in relation to the identification, and control phases of capital investment.

\section{South African surveys of capital budgeting practices}

This paper uses the results of published South African surveys of capital budgeting practices over the period 1972 to 2008 as well as the results of unpublished surveys undertaken by Coltman (1995) and Mokenela (2006). It is important to analyse and compare the sample of firms used in each questionnaire. Often, these are different and the results need be interpreted in terms of the samples used. First of all, almost all surveys and questionnaires are addressed to listed firms, and some surveys are further restricted to the largest firms, for example the Financial Mail top 100 firms. Therefore, these surveys represent different samples and the limitations of using these surveys have already been enumerated. However, the results of surveys which have analysed the use of techniques in relation to capital intensity and the relative size of firms means that certain conclusions as to the use of capital budgeting techniques by smaller firms may to some extent be inferred. Table 1 indicates the sample sizes, populations, and the number of companies responding to each of the ten surveys undertaken in South Africa since 1972.

Table 1: South African surveys on capital budgeting and cost of capital practices

\begin{tabular}{|c|c|c|c|c|}
\hline $\begin{array}{l}\text { Year of } \\
\text { Survey }\end{array}$ & Year Published & Author(s) & $\begin{array}{l}\text { No. of } \\
\text { Firms }\end{array}$ & Sample Used \\
\hline 1972 & 1976 & Lambrechts, I.J. & 48 & Largest firms, FM 100 \\
\hline 1978 & 1981 & Reeve, R.. & 50 & Largest firms, FM 100 \\
\hline 1982 & 1986 & $\begin{array}{l}\text { Andrews, G.S. \& Butler, } \\
\text { F. }\end{array}$ & 132 & Largest firms, 500 firms \\
\hline 1986 & 1990 & Parry, H. \& Firer, C. & 71 & Industrial Listed Companies on the JSE, 270 firms \\
\hline 1987 & 1991 & $\begin{array}{l}\text { Pocock, A., Correia, } \\
\text { C. \& Wormald, M. }\end{array}$ & 40 & Industrial Listed Companies on the JSE, 126 firms \\
\hline 1995 & N/A & Coltman, G. & 37 & $\begin{array}{l}\text { Listed JSE firms - industrial holding, clothing, footwear \& textiles, } \\
\text { engineering firms }\end{array}$ \\
\hline 1998 & $2000 / 2001$ & Hall, J. H. & 65 & Listed JSE firms - industrial sector, 300 firms \\
\hline 1998 & 2003 & Gilbert, E. & 110 & SA Chamber of Business manufacturing member firms \\
\hline 2002 & 2005 & $\begin{array}{l}\text { Du Toit, M.J. \& Pienaar, } \\
\text { A. }\end{array}$ & 67 & All JSE listed companies \\
\hline 2006 & 2008 & Correia, C. \& Cramer, P. & 32 & JSE listed companies (FM 150) \\
\hline
\end{tabular}


Reference is also made to three other surveys. Mokenela (2006) undertook a survey of the use of real option analysis by the top 40 firms listed on the JSE and Brijlal and Quesada (2008) investigated capital budgeting practices by undertaking interviews with businesses in the Western Cape. A further study was undertaken by Gilbert (2005), which involved a case study analysis of capital budgeting practices at two firms.

The lack of consistency of questions asked by the various surveys makes comparisons problematic in relation to specific questions in respect to the application of capital budgeting techniques. Of course, the problem of nonresponse bias needs to be acknowledged, although certain surveys have found non-response bias not to be relevant. Despite these stated limitations, a study of all these surveys over time and a comparison to surveys in other countries lead to interesting conclusions in regard to the theory and practice of capital budgeting in South Africa.

\section{Techniques used in evaluating projects}

It is generally accepted that there has been a significant growth in the use of DCF methods over the last 30 years. Although, DCF methods may represent optimal methods in terms of taking into account the time value of money, risk and cash flows; theoretically, the NPV method should be preferred to the IRR method. In practice, the greatest increase has been in the use of the NPV method. This is particularly true in relation to the capital budgeting practices employed by large capital intensive firms.

The trend in the use of Capital Budgeting techniques since 1972, taking into account the results of all the surveys, is depicted in Figure 1. The years represent the year in which each survey took place rather than the year of publication. What stands out is the significant and steady growth in the NPV method over time. In 1972, only $14 \%$ of companies surveyed used the NPV method, yet by the time of the 2006 survey, $82 \%$ of companies employed NPV to analyse projects. In comparison $64 \%$ of companies used IRR in 1972 and this had grown to 79\% of companies in 2006. Therefore the growth in the use in the NPV method reflects a growing convergence of theory and practice.

In the survey by Coltman (1995) it was found that the most popular method was the payback method with $91,8 \%$ of respondents making use of this method. The Internal Rate of Return was used by $78,3 \%$ of firms whilst $64,8 \%$ of firms used the NPV method. The accounting rate of return (ARR) method was used by $45,9 \%$ of firms whilst $8,1 \%$ of firms used other methods to evaluate capital investments. It is interesting to note the trend in the use of the capital budgeting methods in South Africa in relation to previous surveys undertaken by Lambrechts (1976) in 1972, Andrews and Butler (1986) in 1982, and Parry and Firer (1990) in 1986. Later surveys undertaken by Du Toit and Pienaar (2005) in 2002 and Correia and Cramer (2008) in 2006 indicate a significant fall in the use in the Payback method and the accounting rate of return and growth in the use of IRR and NPV methods.

The general trend portrays an increase in the use of the NPV and the IRR methods, whilst the ARR method has shown a decline in use since 1986. The important trend is that over all the previous surveys, the NPV and IRR methods have shown increasing use and have become more popular in practice. Again, this is particularly true for the NPV method. This is line with financial theory as the NPV and IRR methods take into account the time value of money, risk and are based on cash flows.

The slight variances in trends may be due to the different populations in the surveys. The survey in 1986 included many smaller firms, which means that we would expect a greater emphasis on the use of non-DCF methods as large firms tend to make greater use of DCF techniques. Also, the survey in 1986 referred to the use of return on investment rather than accounting rate of return which may have resulted in differences in interpretation. However, it is significant to note the significant increase in the use of the NPV method for all surveys over the previous 34 years.

\section{Techniques in South Africa}

The survey results for 1998 refer to Gilbert's survey (2003). As Gilbert's survey related to many smaller manufacturing companies, in order to ensure greater comparability, Figure 1 relates to the results for companies in his survey with annual sales that exceeded R100m per year. Later in this study, we will evaluate the use of DCF techniques by smaller firms. Gilbert (2003) further referred to the return on investment (ROI) as a separate method to the accounting rate of return (ARR). It was found that only $23 \%$ of the large companies in his survey used ARR but $77 \%$ of firms used ROI. Again, there may be interpretative and definitional issues regarding the use of ROI. Further, if we include Discounted Payback, with straight Payback, then the combined use rises to $64 \%$ in 2002 and $78 \%$ in 2006 .

The results for South Africa are consistent with the increasing use of DCF methods as indicated by surveys in other countries. (See Blazouske, Carlin \& Kim (1988), Shao \& Shao (1996), Kim \& Ulferts (1996), and Ryan and Ryan (2002).) Pike (1996) undertook a longitudinal survey on capital budgeting practices in the United Kingdom for different years consisting of surveys of the same firms in 1975, 1982, 1986 and 1992. In order to bring Pike's research up to date for the UK, this paper has included the results of a survey undertaken in 1997 by Arnold and Hatzopoulos (2000) and a survey undertaken in 2003 by Alkaraan and Northcott (2006).

The results are depicted graphically in Figure 2 to indicate trends in capital budgeting practices over the intervening period for the UK. 


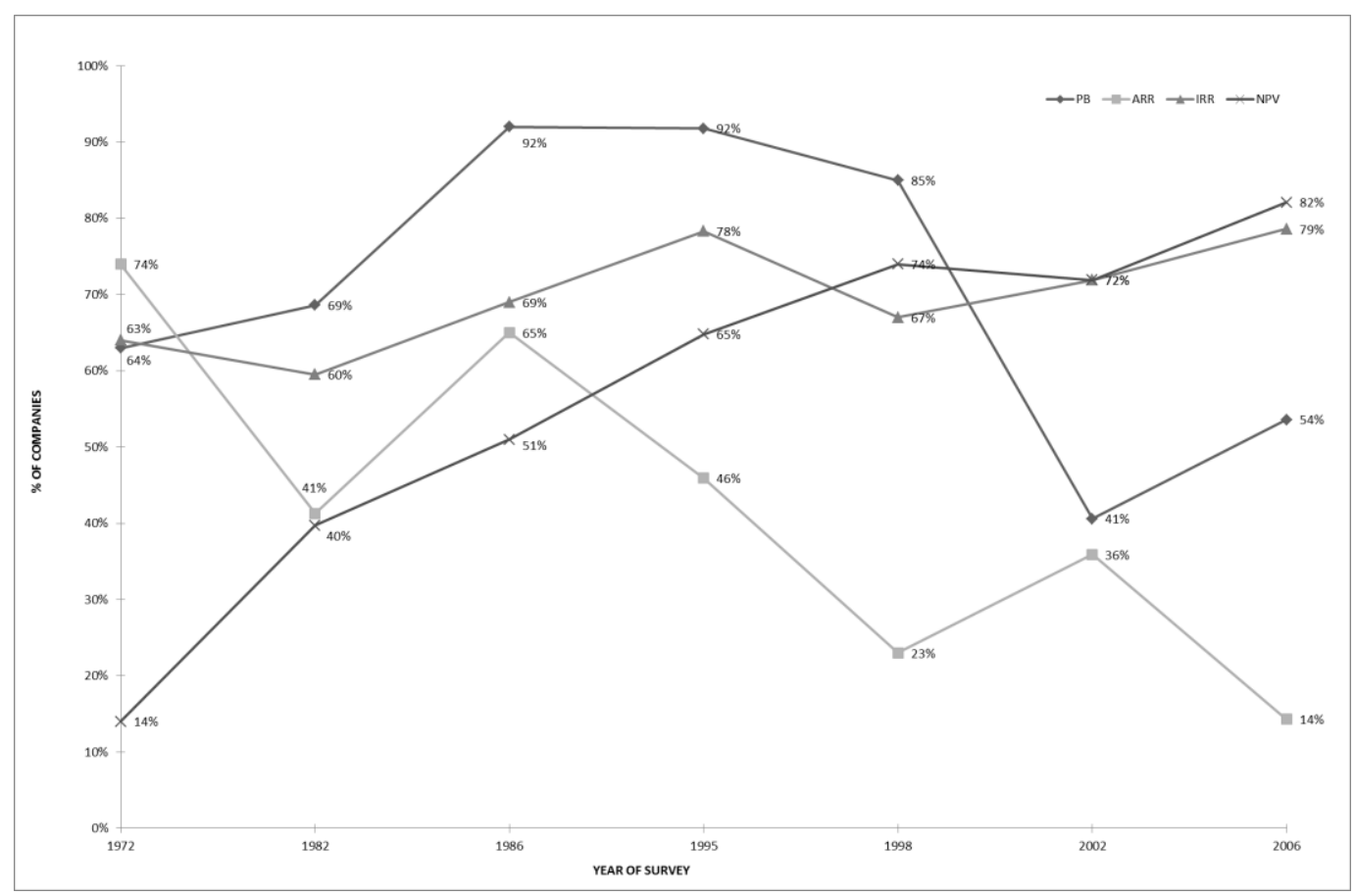

Figure 1: Trends in the use of capital budgeting techniques in South Africa

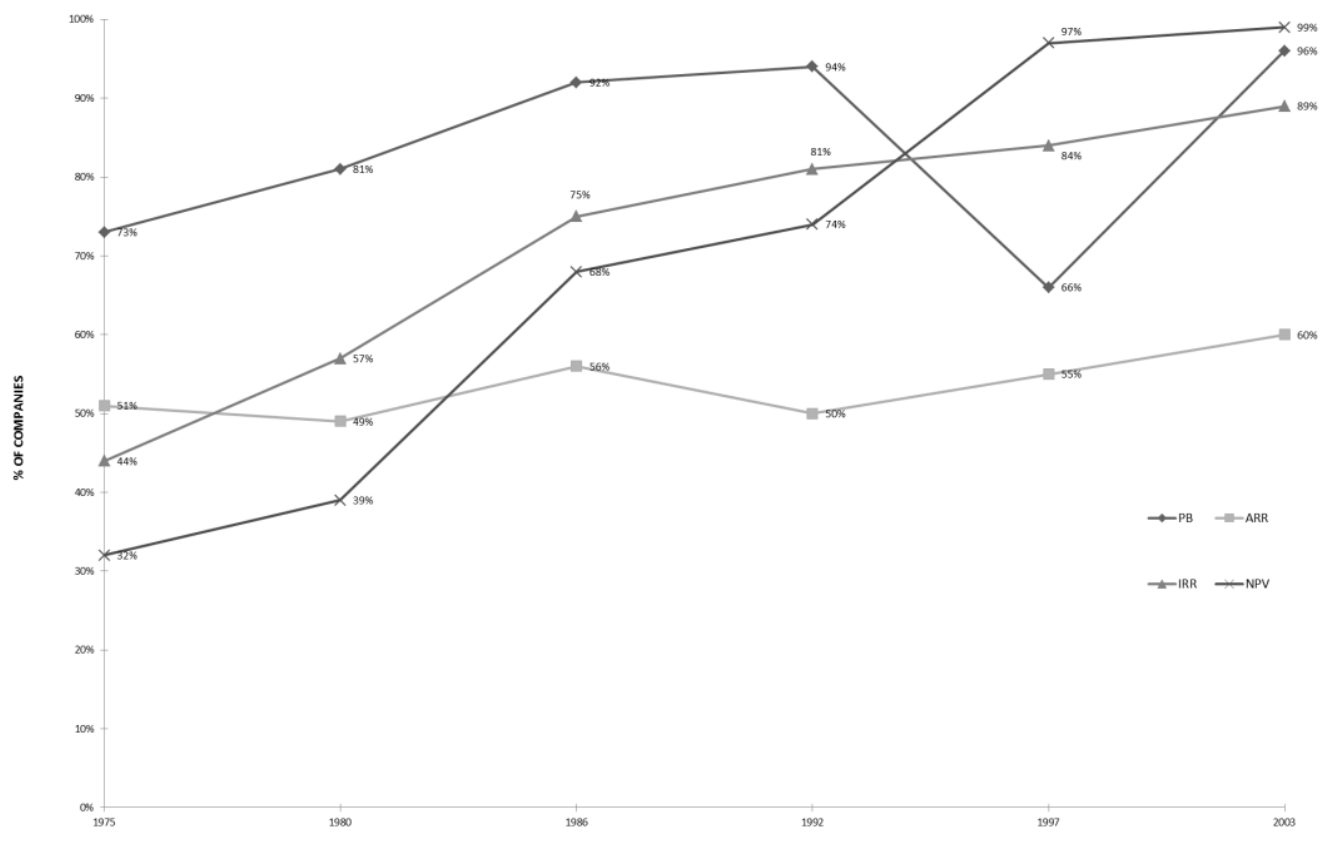

Figure 2: Trends in the use of capital budgeting techniques in the United Kingdom

The results are generally consistent with the findings for South Africa to the extent that there has been a significant growth in the use of the NPV method in the UK, from $32 \%$ in 1975 to $99 \%$ in 2003 whilst the use of IRR has grown from $44 \%$ to $89 \%$ over the same period. Yet, the use of DCF methods is greater in the UK than in South Africa. It is also interesting to note that UK firms make much greater use of the payback method with $96 \%$ of firms making use of this method. The use of the accounting rate of return (ARR) method has remained more constant and significantly exceeds the use of ARR by South African firms.

Initially, the growth in the use of DCF methods internationally was driven by the increase in inflation rates, but particularly by the increase in interest rates during the 1970s (and perhaps due to academic recommendations). Further, in the last 20 years, the growth in use of computer spread-sheets has had a significant effect on the use of DCF and sophisticated capital budgeting techniques. This means that the determination of NPVs and IRRs has become straightforward. This may of course mean that the calculation of NPV is a click away whilst understanding the correct application of NPV may be more elusive. This is a potential problem resulting in erroneous applications of DCF methods.

This is implied in the questionnaire by Lambrechts (1976) and the conclusions reached by Pike (1996) for the UK. Lambrechts (1976) found in undertaking in-depth interviews 
with responding South African firms that the application of all the methods was subject to serious deficiencies.

Although the payback method was found to be traditionally one of the most popular methods used in practice, studies have indicated that it is used as a supplementary method rather than as a primary method in project evaluation. In the survey by Coltman (1995) it was found that by analysing the frequency of usage of various techniques, the payback method was the most popular, but not the most important method. In Australia, Truong, Partington and Peat (2008) found that firms had generally increased their use of DCF methods since 1981, with $94 \%$ of Australian firms making use of NPV and $81 \%$ of firms using IRR whose use had fallen from $96 \%$ in a previous survey in 1999 . The use of the payback method remains high at $90 \%$ whilst $57 \%$ of firms retain the use of the accounting rate of return. The trends in capital budgeting practices for Australia are depicted in Figure 3.
It is interesting to note that there is widespread use of NPV and IRR as well as the Payback method in developing countries such as Malaysia, Indonesia and the Philippines as well in the more developed economies such as the USA, Canada, UK and Australia. However, these survey results relate to large companies in those countries, particularly for the developing countries in South-east Asia. European countries such as the Netherlands, Germany and France indicate a lower use of DCF methods but this may be due to the fact that the survey by Brounen, De Jong \& Koedijk (2004) was sent to 2500 companies thereby including perhaps smaller companies than the other surveys. The overall conclusion is that for larger companies - the use of the NPV and IRR are now dominant whilst payback remains a popular method used in practice. Table 2 sets out the use of capital budgeting techniques in South Africa in the most recent survey, the USA, UK and the Asia-Pacific region.

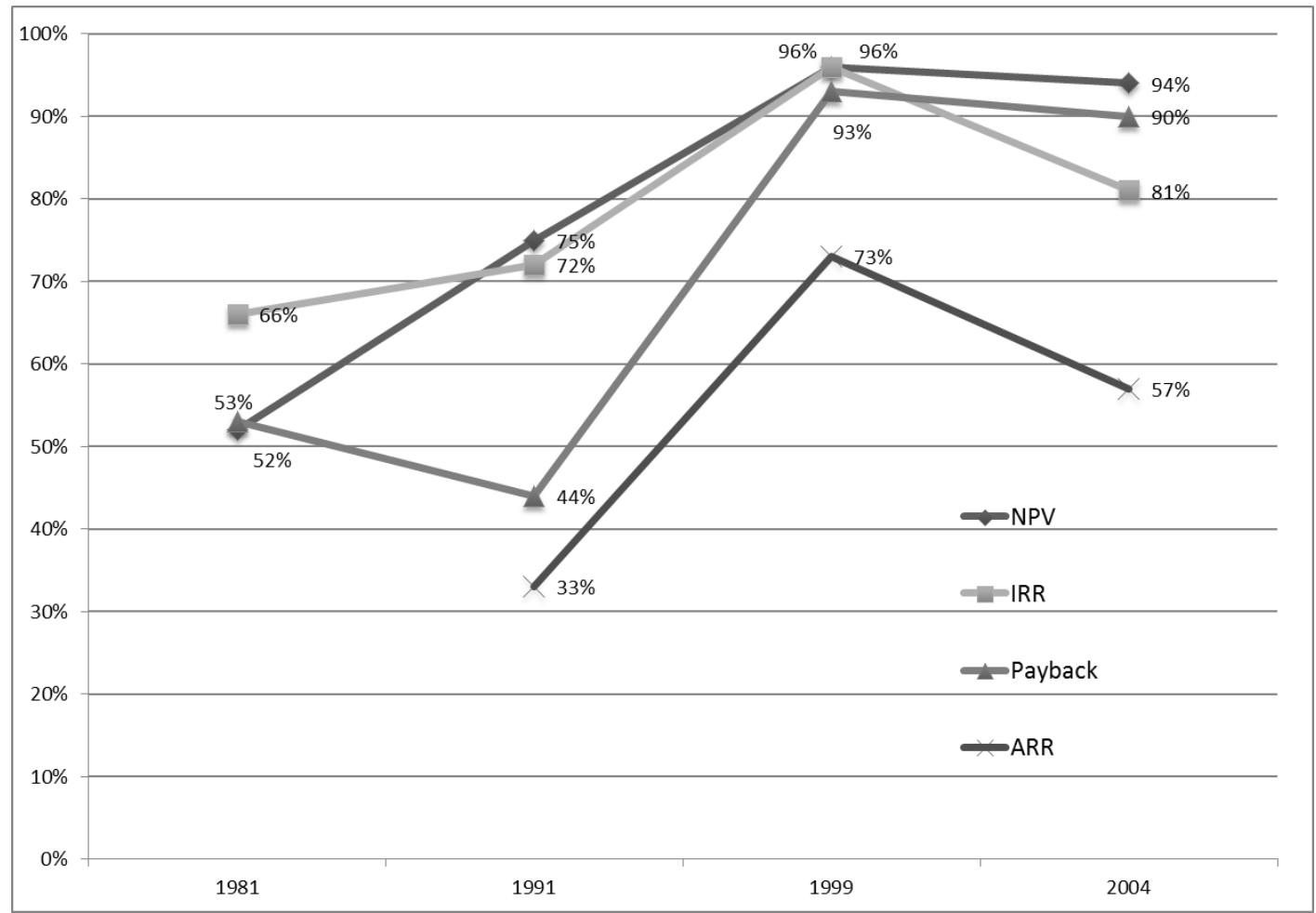

Figure 3: Trends in the use of capital budgeting techniques in Australia

Table 2: Capital budgeting in SA, USA, UK and the Asia-Pacific region

\begin{tabular}{|c|c|c|c|c|c|c|c|c|c|}
\hline Method & $\begin{array}{c}\text { South Africa } \\
\text { Correia \& } \\
\text { Cramer }\end{array}$ & $\begin{array}{c}\text { USA } \\
\text { Ryan \& Ryan }\end{array}$ & $\begin{array}{c}\text { UK } \\
\text { Alkaraan \& } \\
\text { Northcott }\end{array}$ & $\begin{array}{c}\text { Australia } \\
\text { Kester et al }\end{array}$ & $\begin{array}{l}\text { Hong Kong } \\
\text { Kester et al }\end{array}$ & $\begin{array}{c}\text { Singapore } \\
\text { Kester et al }\end{array}$ & $\begin{array}{l}\text { Indonesia } \\
\text { Kester et al }\end{array}$ & $\begin{array}{c}\text { Malaysia } \\
\text { Kester et al }\end{array}$ & $\begin{array}{l}\text { Philippines } \\
\text { Kester et al }\end{array}$ \\
\hline Year of survey & 2006 & 2002 & 2003 & 2004 & 1997 & 1996 & 1997 & 1996 & 1996 \\
\hline Year of publication & 2008 & 2002 & 2006 & 2008 & 1999 & 1999 & 1999 & 1999 & 1999 \\
\hline IRR & $79 \%$ & $77 \%$ & $89 \%$ & $96 \%$ & $86 \%$ & $88 \%$ & $94 \%$ & $89 \%$ & $94 \%$ \\
\hline NPV & $82 \%$ & $85 \%$ & $99 \%$ & $96 \%$ & $88 \%$ & $86 \%$ & $94 \%$ & $91 \%$ & $81 \%$ \\
\hline ARR & $14 \%$ & $15 \%$ & $60 \%$ & $73 \%$ & $80 \%$ & $80 \%$ & $56 \%$ & $69 \%$ & $78 \%$ \\
\hline Payback & $54 \%$ & $53 \%$ & $96 \%$ & $93 \%$ & $100 \%$ & $98 \%$ & $81 \%$ & $94 \%$ & $100 \%$ \\
\hline
\end{tabular}


The results for South Africa are similar to the results of the Ryan and Ryan (2002) survey for the USA, yet in other countries greater use is made of DCF methods as well as ARR and the Payback methods.

In relation to the use of discounted payback, Correia and Cramer (2008) found that $25 \%$ of South African companies use this method whilst Ryan and Ryan (2002) reported that $38 \%$ of US companies used discounted payback. There is limited use of methods such as Profitability Index and Economic Value Added (EVA). Correia and Cramer (2008) found that only $7 \%$ of South African companies determine a project's Profitability Index. The increasing focus on economic profit or EVA means that one would expect to see a growth in the use of this method over time. Yet Correia and Cramer (2008) found that only $14 \%$ of South African companies use EVA to evaluate projects. This is in contrast to the USA, where Ryan and Ryan (2002) reported that $31 \%$ of the firms used EVA to assess capital projects.

\section{Primary methods used in capital budgeting}

Coltman (1995) found that although the payback method was the most popular method with $92 \%$ of firms using this method, it was found that only $48 \%$ of firms used the payback method more than $75 \%$ of the time. It was found that $49 \%$ of firms use the NPV method more that $75 \%$ of the time as compared to $46 \%$ of firms that use the IRR method more than $75 \%$ of the time. Only $27 \%$ of companies employed the ARR method more than $75 \%$ of the time.

The usefulness of the payback method may be to evaluate small projects which may not justify a detailed evaluation employing "sophisticated" techniques such as the IRR and NPV methods. Further, the payback method may be used as an indicator of risk and therefore acts as a supplementary measure rather than as a primary evaluation method. This conclusion is consistent with the findings of other South African surveys which analysed the primary techniques employed by South African firms.

Andrews and Butler (1986) found that $45 \%$ of responding firms reported the IRR as the primary method in evaluating capital projects. In the survey, Andrews and Butler requested companies to report their capital budgeting techniques for 5 years and 10 years previously. The results are depicted in Figure 4. Although this method of determining historical trends in the use of capital budgeting techniques is subject to certain limitations, it may useful to indicate general trends of how companies have modulated reliance on the various methods over the intervening periods.

The use of the NPV method which is supported by theory had shown little growth in the usage by firms as a primary method in the survey undertaken by Andrews and Butler (1986), which asked firms to set out primary methods used in 1971, 1976 and 1982. This conclusion is subject to the proviso that this method has in fact shown the greatest increase in general use and is particularly relevant for large capital intensive firms. Yet the survey by $\mathrm{Du}$ Toit and Pienaar (2005) in 2002 indicated a significant growth in the use of NPV as the primary method used to evaluate capital projects. Yet, the IRR remained as the most important primary method used by South African firms. The trends in the primary technique used for capital budgeting is depicted in Figure 4.

The survey by Hall (2001) in 1998 generally reflected the trends in place, except for the results for ARR. In his survey, Hall specified this as the Return on Investment (ROI) rather than ARR. Consistent with Gilbert (2003) it was found that a high percentage of firms use ROI but this may be due to differences in the definition and interpretation of this term.

Figure 4 depicts a significant and steady increase in the use of NPV as a primary method. Yet IRR remains the most popular primary method used in South Africa. This practice is not aligned with financial theory as IRR is subject to significant disadvantages relative to the NPV method. This relates to possible problems with the IRR arising from the reinvestment assumption, multiple IRRs when the signs of cash flows change and potential incorrect rankings of mutually exclusive projects. Du Toit and Pienaar (2005) specifically requested respondents to select whether IRR or NPV should be used to rank mutually exclusive projects and find in conflict with finance theory that IRR is the preferred method to rank mutually exclusive projects.

Yet, in line with financial theory, there has been a steady decline in the use of Payback as a primary method and the ARR has also fallen in use as a primary indicator for all surveys except for the survey by Hall (2000).

\section{Project risk analysis}

Risk analysis is a critical aspect of the capital budgeting process. Risk analysis involves the assessment of risk and the adjustment for risk. The assessment of risk may involve the use of sensitivity analysis, scenario analysis, probability analysis, decision trees and Monte Carlo simulation. These techniques measure the variability of returns, the probability of not meeting a required return or the potential downside risk of the project resulting in significant losses for the firm. Adjusting for project risk may involve altering a firm's WACC, shortening the required payback or reducing project cash flows.

Surveys by Correia and Cramer (2008) find that there is a low utilisation of sophisticated risk methods to assess project risk. Firms in South Africa do not use methods such as Probabilities, Decision trees and Monte Carlo Simulation to any great extent and there has been little growth in the use of such methods in practice. Firms have traditionally made greatest use of Sensitivity Analysis and surveys (see Parry \& Firer (1990); Pocock, Correia \& Wormald (1991); Coltman, (1995)) found this to be the most important single method for determining project risk. Although, Sensitivity Analysis evaluates each variable in isolation, it is considered that firms undertake scenario type analysis using the same technique and there has been a significant growth in the use of Scenario Analysis over time. Recently, Scenario Analysis has become the most popular risk assessment method in South Africa as indicated by the Correia \& Cramer (2008) survey. 


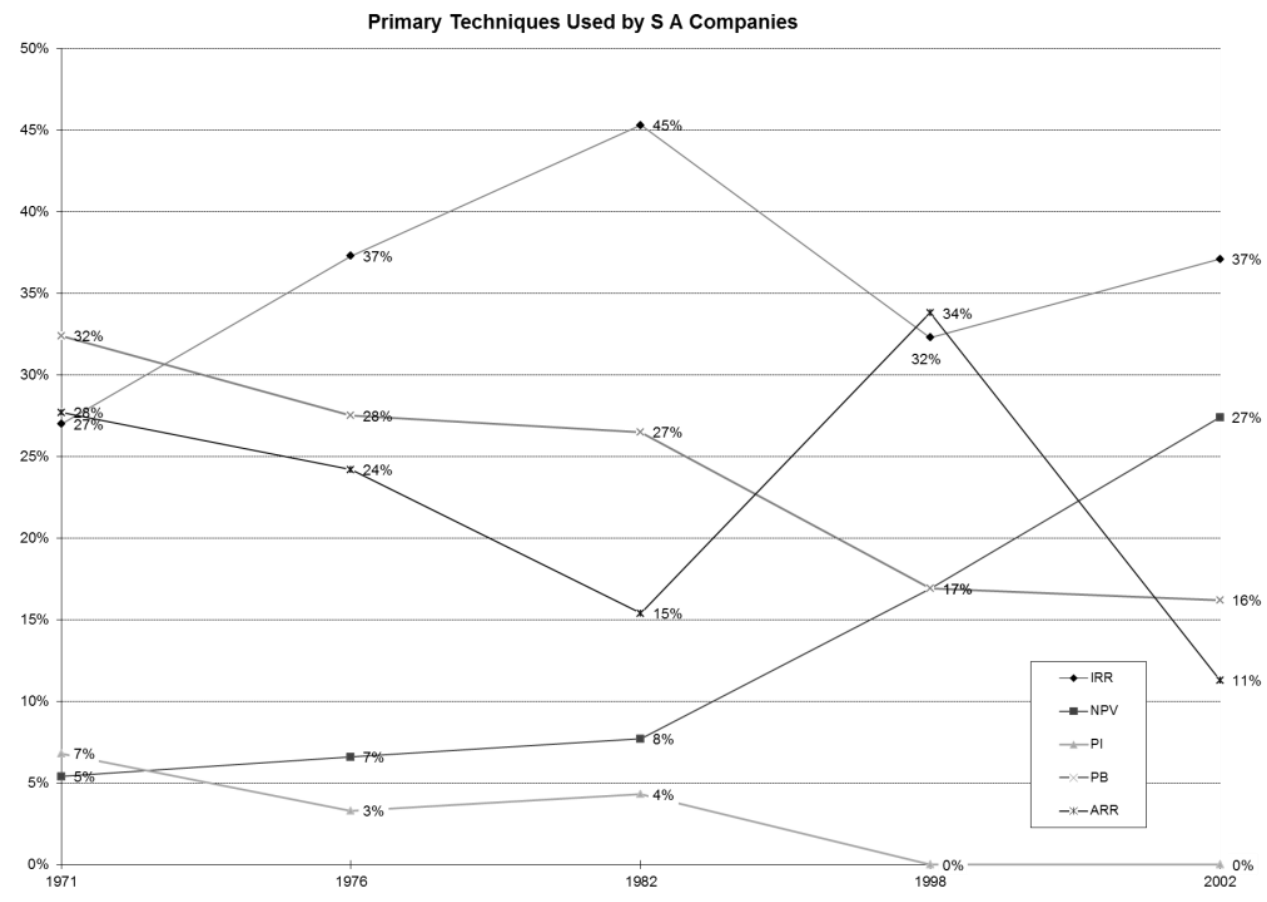

Figure 4: Primary techniques used by South African companies

The use of sensitivity analysis by UK companies over time is indicated by Pike (1996), Arnold and Hatzopoulos (2000) and a survey undertaken in 2003 by Alkaraan and Northcott (2006). The use of sensitivity analysis as indicated by South African and UK surveys is depicted in Figure 5. The UK study combined the use of sensitivity analysis and scenario analysis and therefore due to the increased use of scenario analysis in South Africa, the combined total for sensitivity/scenario analysis is expected to be greater than indicated in Figure 5.

There has also been a growth in the use of various methods to assess and adjust for risk. Parry and Firer (1990) in 1986 found that $61 \%$ of firms employed sensitivity analysis in assessing risk and this had grown to $68 \%$ of firms in the Correia and Cramer (2008) survey undertaken in 2006. The quantitative methods used by firms, as determined by Parry and Firer (1990) in their 1986 study was compared to the use of the same quantitative methods in 2006 and the results are presented in Figure 6.

Correia and Cramer (2008) in their 2006 survey found that $50 \%$ of firms also use break-even analysis to evaluate risk. As this is linked with sensitivity and scenario analysis, this reinforces the dominance of these methods in practice.

In another study Pocock, Correia and Wormald (1991) found that $58 \%$ of firms employed Sensitivity Analysis whilst only $15 \%$ of firms used simulation. These results support the conclusions of Parry and Firer (1990) and Correia and Cramer (2008) that there is a low usage of Monte Carlo (computer) simulation but a much higher use of sensitivity analysis. Pocock, Correia and Wormald (1991) also found that $15 \%$ of firms surveyed employed Beta Analysis in risk appraisal and the rand size of the project and its payback period were important in assessing risk.
Therefore, Figure 6 indicates limited growth in the use of such sophisticated methods as decision trees and Monte Carlo simulation over the 20 years from 1986 to 2006.

Hall (2001) in 1998 investigated the risk analysis techniques employed by South African firms. The results add up to $100 \%$ and it is assumed that firms have responded by indicating the most important method employed rather than which methods were used (which would add up to more than $100 \%$ ). Interestingly, Hall reported that $37 \%$ of South African firms do not employ risk analysis in project evaluation. Sensitivity analysis was the most important method used by $31 \%$ of firms.

It is relevant to distinguish between risk assessment and risk adjustment. Risk assessment refers to the process of measuring project risk while risk adjustment refers to the method used to include risk in the process of project evaluation, such as increasing the required hurdle rate by a risk premium or shortening the required pay-back period. Risk assessment is used to determine the required risk premium whilst risk adjustment is the inclusion of the risk premium in the method of project evaluation.

In the United Kingdom, Pike (1996) recorded the increases in the use of risk appraisal techniques for capital budgeting, however, Pike (1996) does not appear to differentiate between risk assessment and risk adjustment.

Pike indicated that the most popular risk appraisal method was found to be the use of Sensitivity Analysis. This is followed by the use of shortened payback and the adjustment to the required return. Probabilities and Beta analysis have shown increases in usage off low bases. 


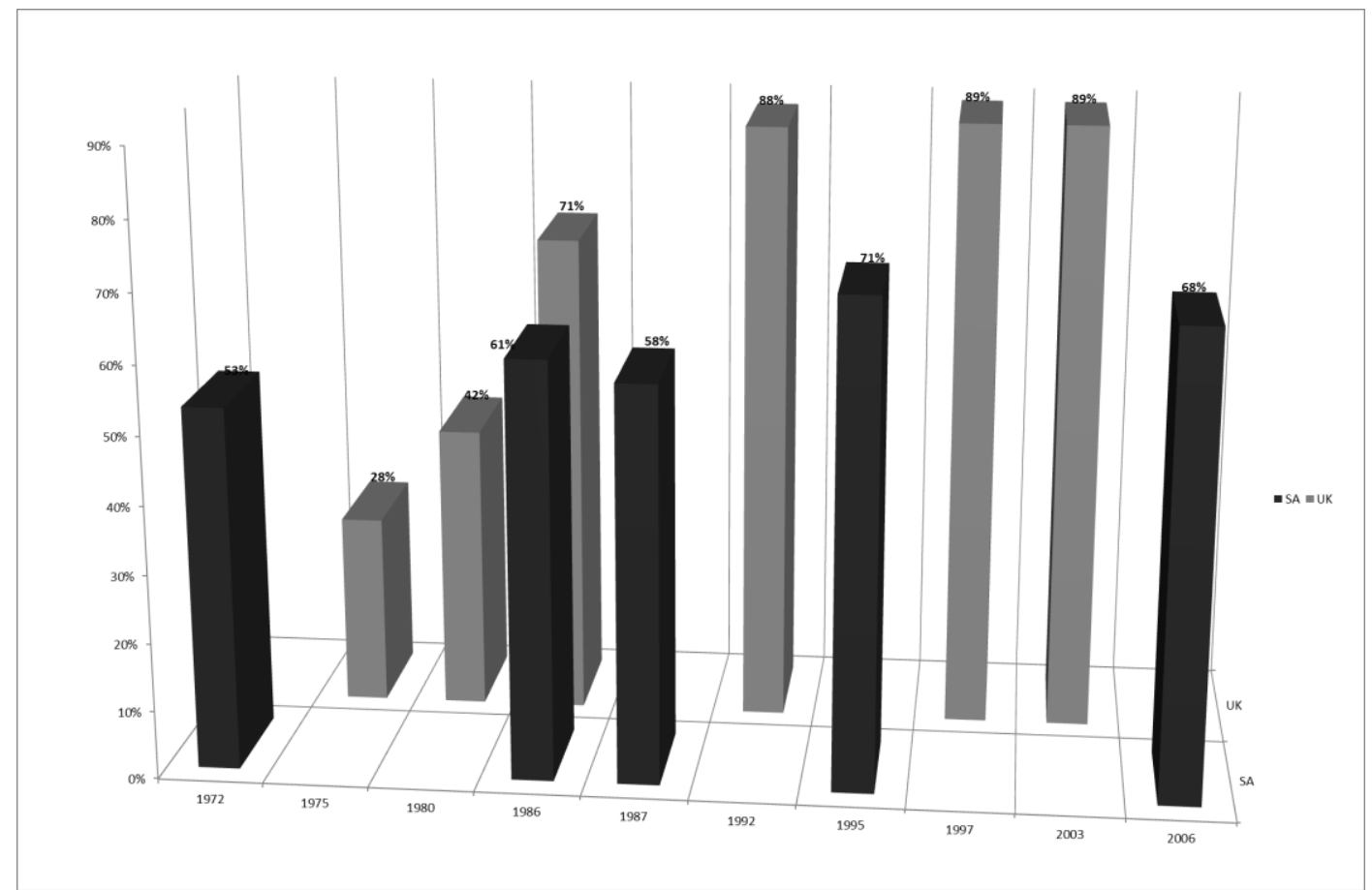

Figure 5: The use of sensitivity analysis in SA and the UK

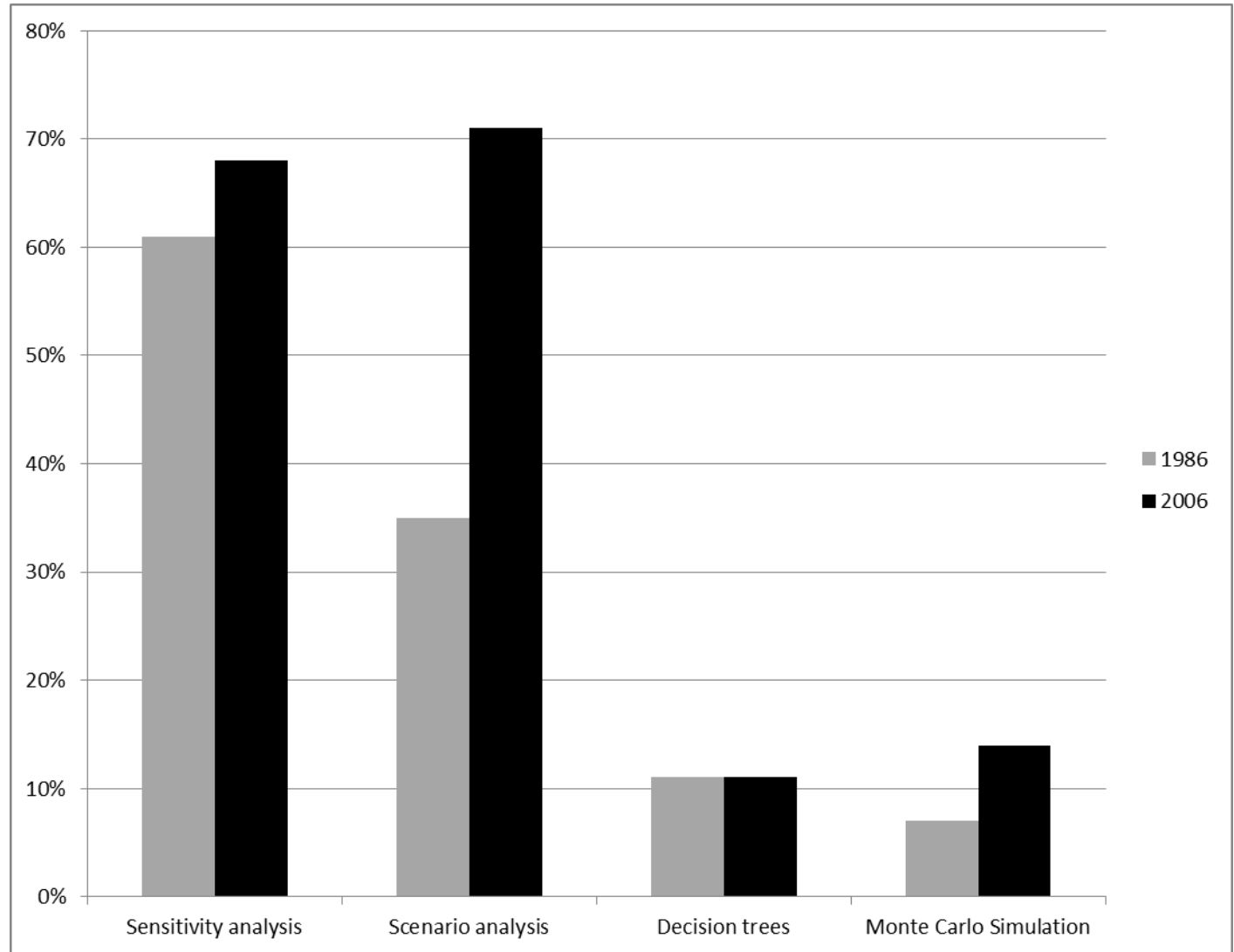

Figure 6: Quantitative methods used to assess risk 
Ryan and Ryan (2002) report for the USA, that $65 \%$ of companies always or often use sensitivity analysis, and $42 \%$ of companies use scenario analysis. The study found that $19 \%$ of companies used simulation and $8 \%$ used decision trees.

In conclusion, South African companies tend to focus on the use of sensitivity/scenario analysis to assess project risk. South African companies lag more developed countries in the use of sophisticated risk analysis methods such as decision trees, probability distributions and Monte Carlo simulation although in countries such as the USA, use of these methods is also limited.

\section{The use of risk adjusted discount rates}

In the Parry and Firer (1990) survey, the most common method to adjust for risk was the use of a risk adjusted hurdle rate. This was used by $32 \%$ of the responding firms. In Pocock, Correia and Wormald (1991) it was found that $35 \%$ of companies employed the cost of the specific source of finance for the project as the discount rate, whilst the balance of companies used the cost of capital.

Reeve (1981) found that only $20 \%$ of companies employed the weighted average cost of capital to evaluate projects, $20 \%$ of companies used the bank overdraft rate whilst $60 \%$ of companies set the discount rate as a matter of management policy (i.e. in a subjective manner). Yet Reeve also found that $70 \%$ of companies indicated that they varied the rate for individual projects. Coltman (1995) reported that only $21 \%$ of firms used the cost of capital, $50 \%$ of firms did not specify any method and $29 \%$ used a rate based on the borrowing rate plus a premium. Parry and Firer (1990) also found that $31 \%$ of firms used the weighted average cost of capital as the discount rate to evaluate projects.

Hall (2001) reported that only $12 \%$ of firms adjusted the required rate of return whilst $6 \%$ of firms shortened the required payback period. Risk assessment and risk adjustment were consolidated in his survey of risk analysis techniques. The use of simulation, probability theory and standard deviation were below 5\% of companies for each method. The differences in results may be due to differences in samples as Hall's survey related to companies listed in the Industrial sector of the JSE Securities Exchange.

Gilbert (2003) reported that only $28 \%$ of the large South African companies included in his survey in 1998 adjusted the discount rate to incorporate project specific risk. This is not in line with finance theory which recommends the use of risk adjusted discount rates. However, adjustments were made to the hurdle rate by $67 \%$ of the large companies if there were changes in external conditions and $44 \%$ of large companies adjusted the hurdle rate due to changes in internal conditions. It would have been useful to have asked companies whether adjustments were made to cash flows or if the required project's payback was shortened in order to adjust for project risk.

In relation to the adjustment for risk for the UK, Alkaraan and Northcott (2006) found that $82 \%$ of companies raised the required rate of return whilst $75 \%$ of firms shortened the required payback of a project. The survey also found that $43 \%$ of firms employed beta analysis and $77 \%$ of firms employed probability analysis. Therefore, firms in the UK are far ahead of their South African counterparts when it comes to adjusting for risk. Truong, Partington and Peat (2008) found that 57\% of firms in Australia used the firm's discount rate to discount project cash flows. Therefore the majority of companies in Australia did not adjust the discount rate for specific project risk.

In a study of companies in the Asia-Pacific region, Kester et al. (1999) found that the majority of companies in all countries (except for the Philippines) used either a single discount rate or used the cost of the specific capital used to finance the project (for example, if a project used only debt finance, then the discount rate used was the cost of debt). This is presented in Table 3.

Although a high percentage of companies employ DCF methods in the Asia-Pacific region, the use of a single discount rate is not aligned with finance theory. Far worse, is the high use (except for Australia) of the cost of the specific source of capital used to finance the project, as the discount rate. This is fundamentally not aligned with finance theory. In the USA, according to Graham and Harvey (2001), 59\% of companies were found to always or almost always use the discount rate for the entire company.

Correia and Cramer (2008) found that $57 \%$ of CFOs always or almost always used the discount rate for the entire company. However, the study also found that $57 \%$ of CFOs also use risk-adjusted discount rates for projects. This may indicate that where projects reflect the average risk of the company, then the discount rate for the firm is used, whilst a risk-adjusted discount rate is employed when the risk of the project differs from the risk of the firm. However, Gilbert (2003) states that $80 \%$ of companies do not adjust hurdle rates to reflect project specific risk. The companies surveyed in Correia and Cramer (2008), represent large listed companies and therefore the higher use of risk adjusted discount rates by firms in their survey may reflect differences in firm size.

A number of the surveys indicate that most companies in South Africa do not use risk adjusted discount rates to evaluate capital projects. However this is also true for other countries such as the USA and countries in the Asia-Pacific region. The survey evidence is at best ambiguous in relation to the use of risk-adjusted discount rates to discount project cash flows. Finance theory indicates that firms should employ risk-adjusted discount rates to discount project cash flows. 
Table 3: Capital budgeting in SA, USA, UK and the Asia-Pacific region

\begin{tabular}{|c|c|c|c|c|c|c|}
\hline Discount rate & Australia & Hong Kong & Singapore & Indonesia & Malaysia & Philippines \\
\hline Single discount rate (WACC of the firm) & $48 \%$ & $24 \%$ & $11 \%$ & $29 \%$ & $29 \%$ & $16 \%$ \\
\hline Risk adjusted discount rate & $38 \%$ & $19 \%$ & $38 \%$ & $29 \%$ & $24 \%$ & $52 \%$ \\
\hline Cost of specific source of capital (Ex. cost of debt) & $14 \%$ & $57 \%$ & $51 \%$ & $43 \%$ & $47 \%$ & $32 \%$ \\
\hline
\end{tabular}

Yet, South Africa is not alone; the survey evidence from many countries indicates that incorrect procedures such as use of the specific rate of financing the project, or the use of a single firm discount rate continues to be used by the majority of firms. It would be useful for future research to determine the reasons why practice in this area is not aligned with financial theory.

\section{The use of DCF methods and firm size}

There is a link between the usage of DCF methods and the size of the firm and/or the level of the firm's capital intensity. The larger and more capital intensive the firm, the higher is its use of DCF methods. This is true internationally as well as in South Africa. Danielson and Scott (2006) report that only $12 \%$ of small firms in the USA use DCF as a primary method to evaluate projects.

Also, some studies (see Parry \& Firer, 1990; Coltman, 1995) have shown that large firms will use the NPV method to greater extent than the IRR method and that the growth in the use of the NPV method has shown its greatest use in large firms. Andrews and Butler (1986) also found that the size of the capital budget was significantly related to the use of the DCF methods particularly the NPV method which for firms with capital budgets of over R50m represented the most widely used technique. Coltman (1995) also found a significant relationship between the size of capital budgets and the use of sophisticated techniques with $82 \%$ of companies with capital budgets above R50m using NPV whilst only $40 \%$ of all companies used NPV.

Parry and Firer (1990) found that $86 \%$ of capital intensive firms used quantitative methods to assess risk as compared with only $39 \%$ of those firms which were less capital intensive.

Yet Hall (2000) found that firms with larger capital budgets tended to employ IRR rather than NPV. Du Toit and Pienaar (2005) find that either IRR or NPV is used as the primary method for annual capital budgets greater than R500m. Up to R50m, companies may also use Payback, ARR or Discounted Payback as a primary method.

However, it is interesting to note that in the survey by Du Toit and Pienaar (2005), IRR dominates as primary method for annual capital budgets over R5m. This is surprising due to the stated disadvantages of IRR. This is presented in Figure 7. However, Du Toit and Pienaar (2005) also find that for the resources and mining sector, NPV is the dominant capital budgeting method.

The survey by Gilbert (2003) represented mostly smaller companies in relation to other major surveys in South Africa but he has divided responses by large, medium and small companies. The results for the large and small companies are interesting and are depicted in Figure 8. Whilst large companies tend to use all methods, small firms hardly use IRR and NPV to evaluate projects.

Brijlal and Quesada (2008) in a survey of mostly small firms in the Western Cape found that 39\% of firms used Payback, $36 \%$ of firms used NPV, $28 \%$ of firms used IRR, $22 \%$ of firms used ARR and $28 \%$ of firms used the Profitability Index. This means that few firms used more than one method and this study found that the use of DCF methods was also linked to level of formal qualifications of the decision maker. DCF methods were more often used by decision makers with a post-graduate qualification. In a further break-down of results between large and small firms, Brijlal and Quesada (2008) found that 50\% of large firms used NPV whilst only $27 \%$ of small firms used NPV. The most important method for small firms is the payback method.

In conclusion, surveys have indicated that small firms make lower use of DCF methods such as IRR and NPV to evaluate projects and make greater use of Payback and ROI. Although some surveys find that larger firms make greater use of IRR in relation to NPV, most surveys to date find that larger firms make greater use of NPV. Although the use of IRR remains important and is the most used primary method, there has been a significant increase in the use of NPV.

\section{Combination of techniques used to evaluate projects}

There has been a significant growth in the use of a combination of capital budgeting techniques to evaluate projects. This is reflected in the results from surveys undertaken in the USA, the UK and in SA. In the UK, Pike (1996) found a significant increase in the use of a combination of techniques to evaluate projects, with firms employing, on average, 3 methods to evaluate capital projects. Alkaraan and Northcott (2006) found that $88 \%$ of companies in the UK used three or more techniques to evaluate projects. Figure 9 depicts the average number of techniques used to evaluate projects in South Africa.

Andrews and Butler (1986) in their 1982 survey found that the average number of techniques used by each firm was 2,31 methods. Coltman (1995) found that for all companies included in the sample, the average number of methods used by South African firms had increased to 2,89 methods. Gilbert (2003) in a survey undertaken in 1998 reported that the average number of techniques used by South African companies was 3,0 methods. This reflects a significant increase in the number of methods used by South African firms to evaluate capital budgeting decisions. 


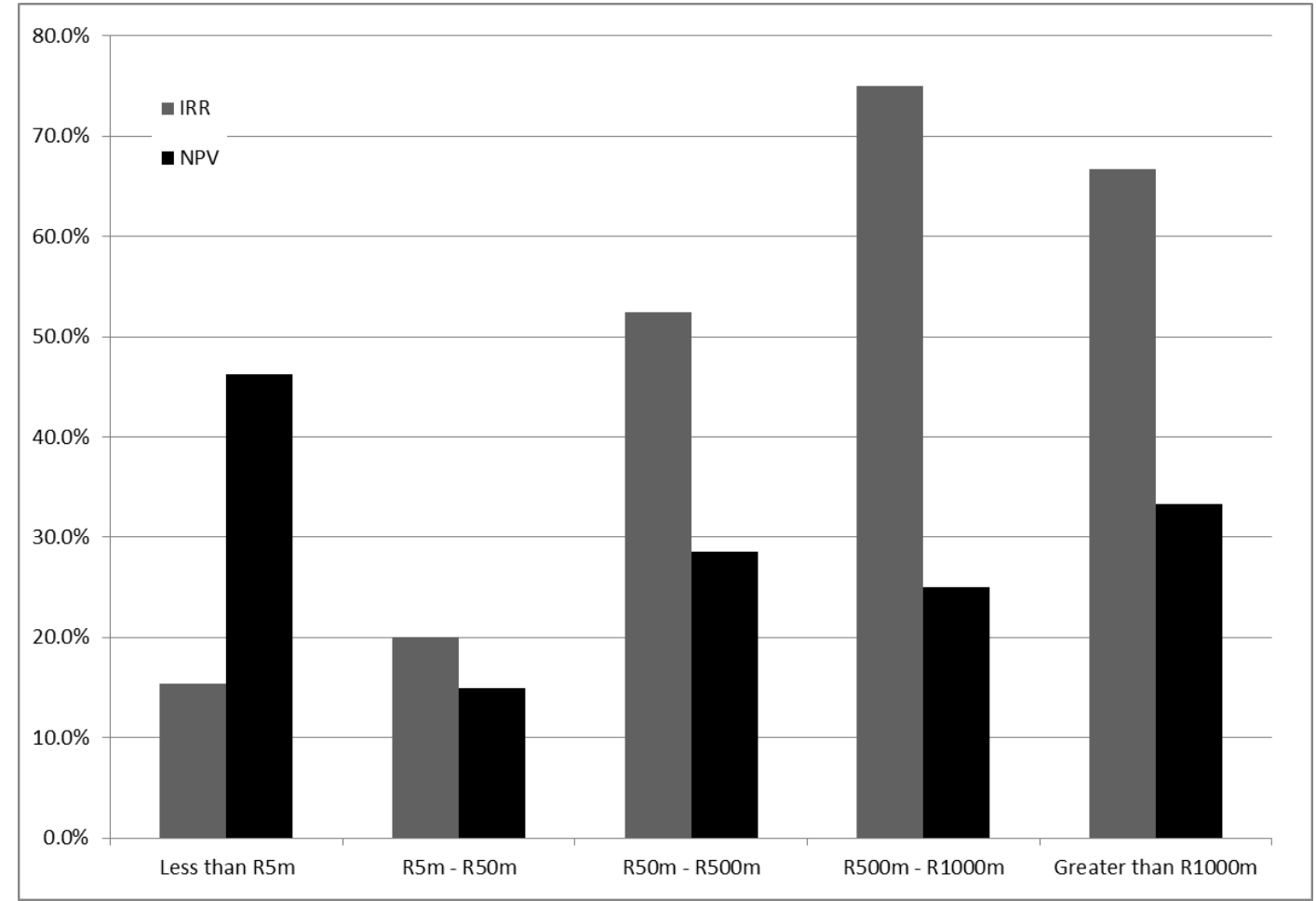

Figure 7: Use of NPV and IRR and the size of the capital budget

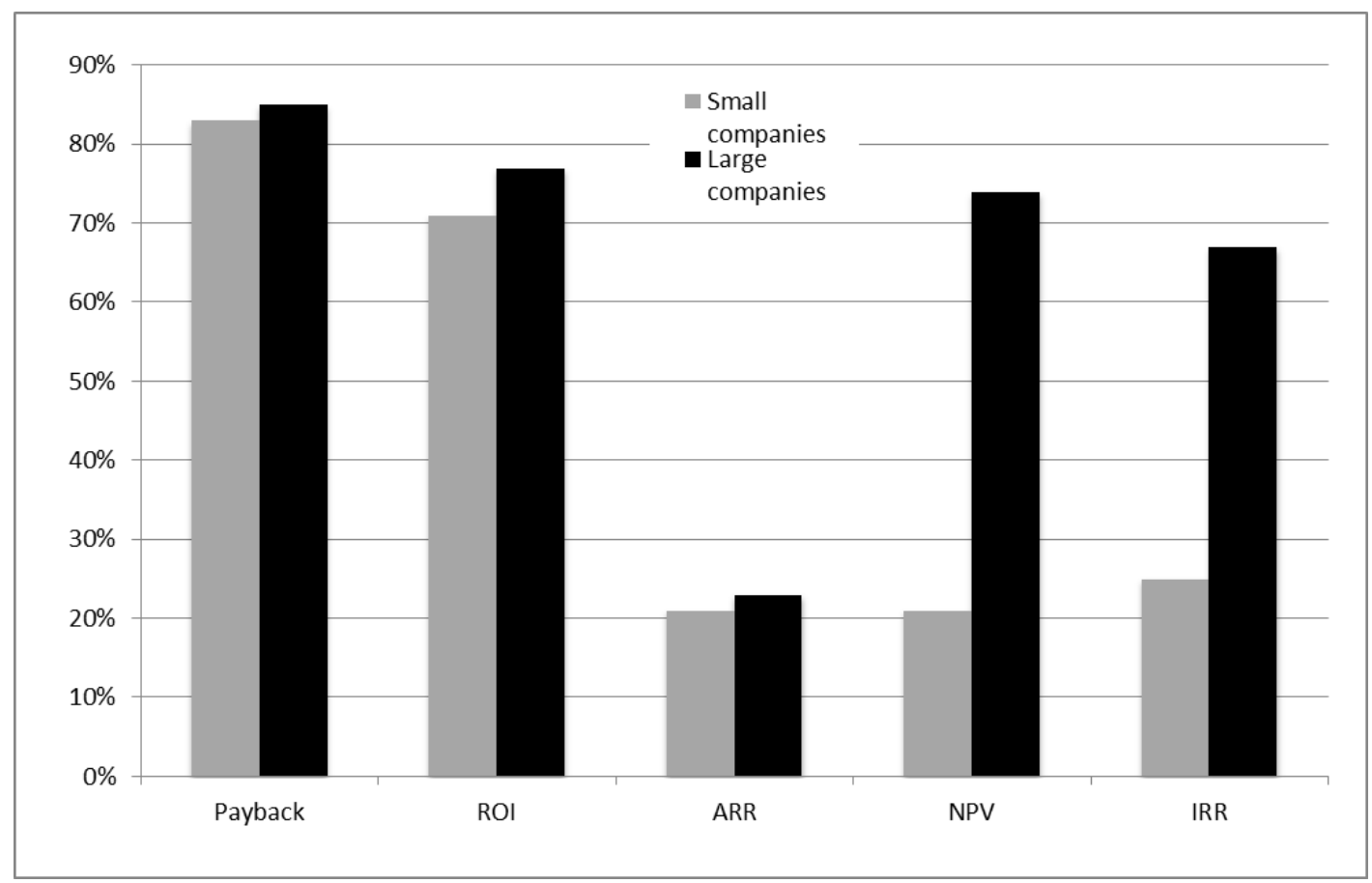

Figure 8: Firm size and the use of capital budgeting methods 


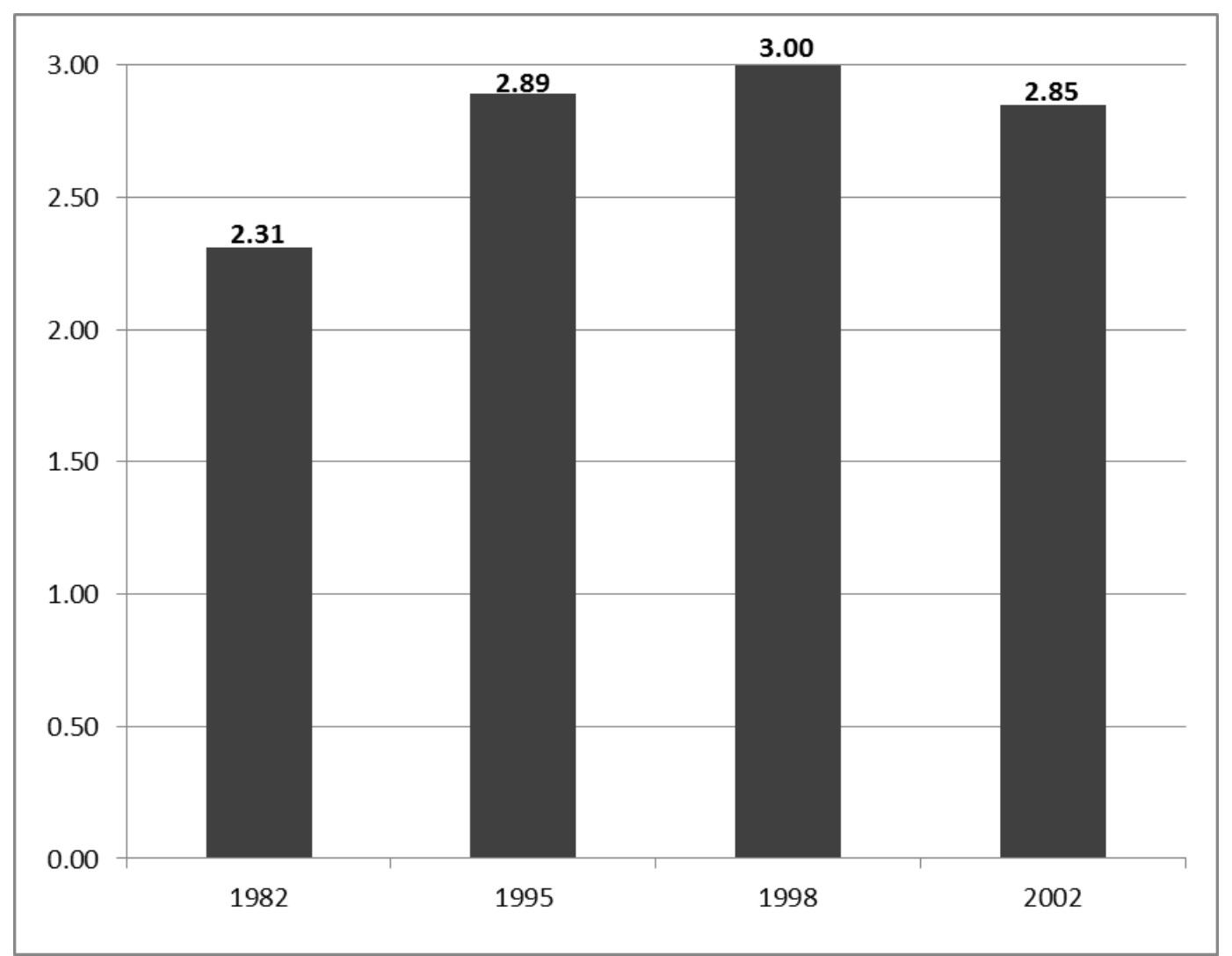

Figure 9: Number of capital budgeting techniques used to evaluate projects

Andrews and Butler (1986) found that there was a significant difference between the average number of methods used by firms with capital budgets of greater than R50m (2,99 methods) as compared to firms with capital budgets of less than R2m (1,70 methods). The increasing use of combined evaluations may reflect management endeavouring to reduce uncertainty in the use of capital budgeting methods as well as reporting all measures of investment performance.

\section{Post completion audits of capital projects}

There has been an improvement in the use of post-decision controls. This is most obvious in comparing the use of post completion audits in the United Kingdom over time. In South Africa, only Lambrechts (1976) and Coltman (1995) addressed this issue. Yet the results in the Coltman survey indicate that $87,5 \%$ of firms did undertake post completion audits of capital projects while Lambrechts (1976) found that $74 \%$ of the manufacturing firms included in his sample performed post completion audits.

This represents an increase in the post decision control of projects, although the increase in the use of audits would be expected to be greater over such a lengthy period. The results for Lambrechts should be interpreted in terms of the companies used in his sample which represented large manufacturing companies, and therefore were expected even at that time to undertake post completion audits. Pike (1996) reported a steady increase in the use of post completion audits in the UK. Figure 10 depicts the percentage of companies undertaking post-completion audits in South Africa and the UK over time.
Correia et al. (2007: 8-30 to 8-31) set out the advantages and disadvantages of post-completion audits and also express the view that post-completion audits should not only apply to projects that were accepted but also to projects that were rejected.

Interestingly, Soares, Coutinho and Martins (2007) found in post-completion audits of investment projects in Portugal that forecasts of future sales were mostly subject to overoptimistic assumptions and were subject to significant forecasting errors whilst forecasts of future operating costs were more accurate.

This conclusion is supported by the results of a global McKinsey \& Co. survey (2007) which reported that estimates of future sales and project duration tend to be "overly optimistic". The same survey found for 31\% of projects rejected in the prior three years that such rejection had been in error, whilst $19 \%$ of projects accepted in the prior three years should have been rejected. Future research is required to evaluate the issues investigated in postcompletion audits in South Africa.

Post-completion audits and future research in this area will assist our understanding of the project definition and cash flow estimation phase of capital budgeting (see Hall, 2000). We will address the phases of capital budgeting later in the study.

The application of capital budgeting techniques is dependent on the correct adjustment for issues such as inflation, taxation and reinvestment rates. An analysis of these issues in the survey results indicates the level of sophistication in the application of these techniques and whether they are being correctly applied in practice. 


\section{Treatment of inflation}

It is important to note the adjustments required to take into account inflation. In the $1970 \mathrm{~s}$, most South African firms were employing nominal discount rates to discount cash flows stated in current prices. This is reflected in the survey undertaken by Reeve (1981) in 1978 which also determined the estimated nominal cost of capital to be $15 \%$. This also reflected the average discount rate used by firms in the survey. The use of a nominal rate means that firms should use nominal cash flows in project evaluation. However, only $14 \%$ of the responding firms which took part in Reeve's survey adjusted cash flows for inflation. This would result in a serious bias against investment in capital projects as expected cash flows (the numerator) did not include inflation, while the discount rate (the denominator) included inflation. Yet, 17 years later Coltman (1995) found that $87.5 \%$ of firms were now adjusting future cash flows for expected inflation. The increase in the percentage of firms adjusting cash flows for inflation is depicted in Figure 11. Further, Hall (2001) from his 1998 survey reported that $77 \%$ of firms make some adjustment for inflation and most firms use various inflation rates for different annual cash flows.

In the United Kingdom, Pike (1996) found that there had been a significant increase in the number of firms making explicit adjustments for inflation, $58 \%$ of firms made adjustments for changes in general inflation while $56 \%$ of firms specified different rates for all costs and revenues. However, it is interesting to note that Pike (1996) found that $70 \%$ of firms estimated future cash flows at constant prices and discounted the project cash flows at a real discount rate. This method is only consistent with financial theory if future cash flows are expected to increase at the general rate of inflation and income tax capital allowances (based on historical cost) are not applicable. These assumptions are generally not sustainable in a real world context and therefore the results indicated are surprising in relation to the increasing sophistication of capital budgeting techniques employed in the UK.

Ryan and Ryan (2002) found for the USA that only $31 \%$ of companies employed inflation adjusted cash flows. Although, this may be due to low inflation rates in the USA, it is a fact that even an annual inflation rate of $3 \%$ compounded over the long term will have a material effect on the value of a capital project. This is further supported by the fact that Ryan and Ryan (2002) found that $83 \%$ of companies used the WACC as the project discount rate, which is a nominal rate. Discounting real cash flows by a nominal rate is not aligned with finance theory. In respect to adjusting future cash flows for inflation, South African firms are generally ahead of their USA counterparts. However, Waweru, Hoque and Uliana (2005) report, when testing the appropriateness of inflation adjustments, that only $28 \%$ of South African firms made the correct adjustment for inflation by either discounting future inflation adjusted cash flows at a nominal discount rate or by discounting real cash flows at the real required return.

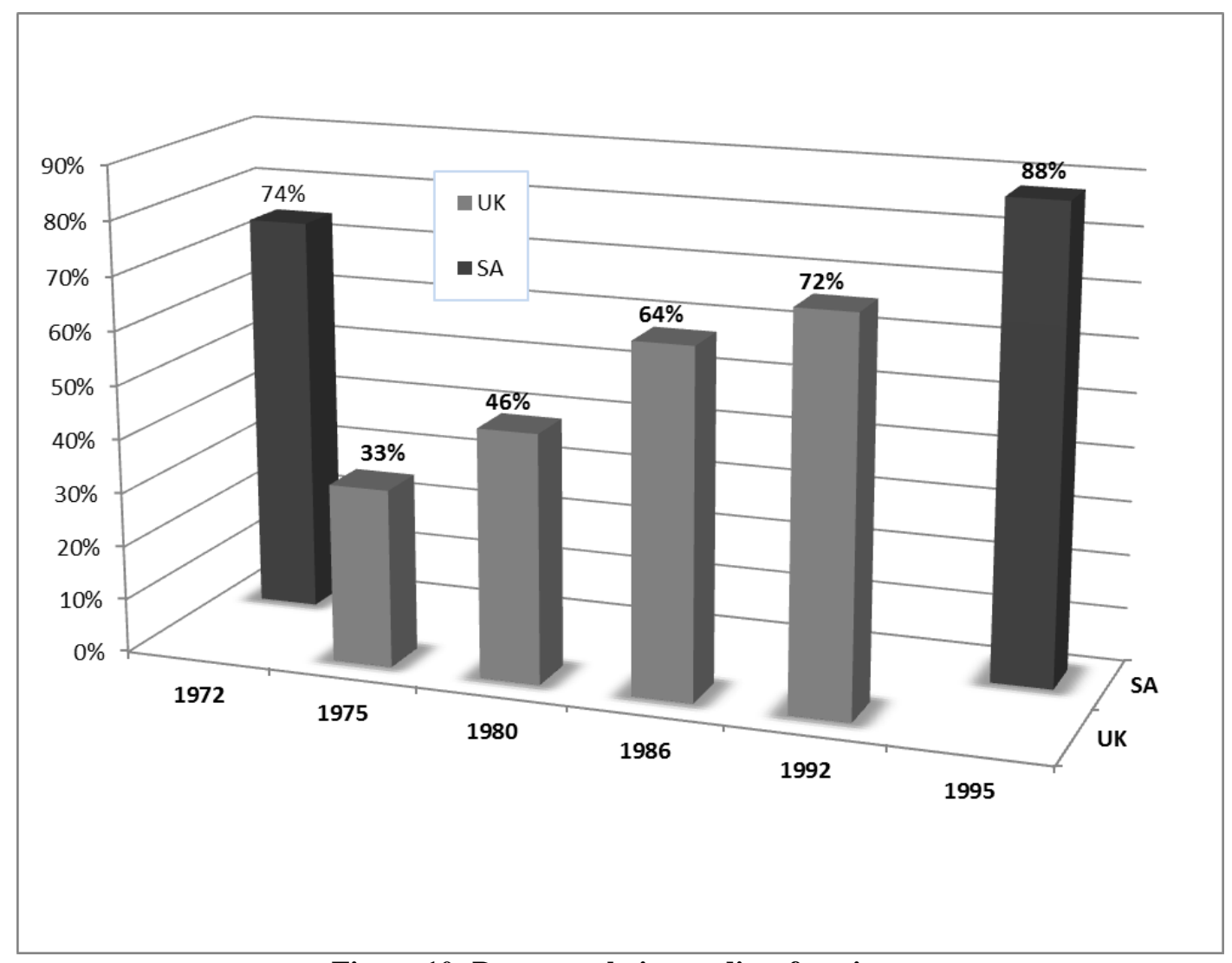

Figure 10: Post-completion audits of projects 


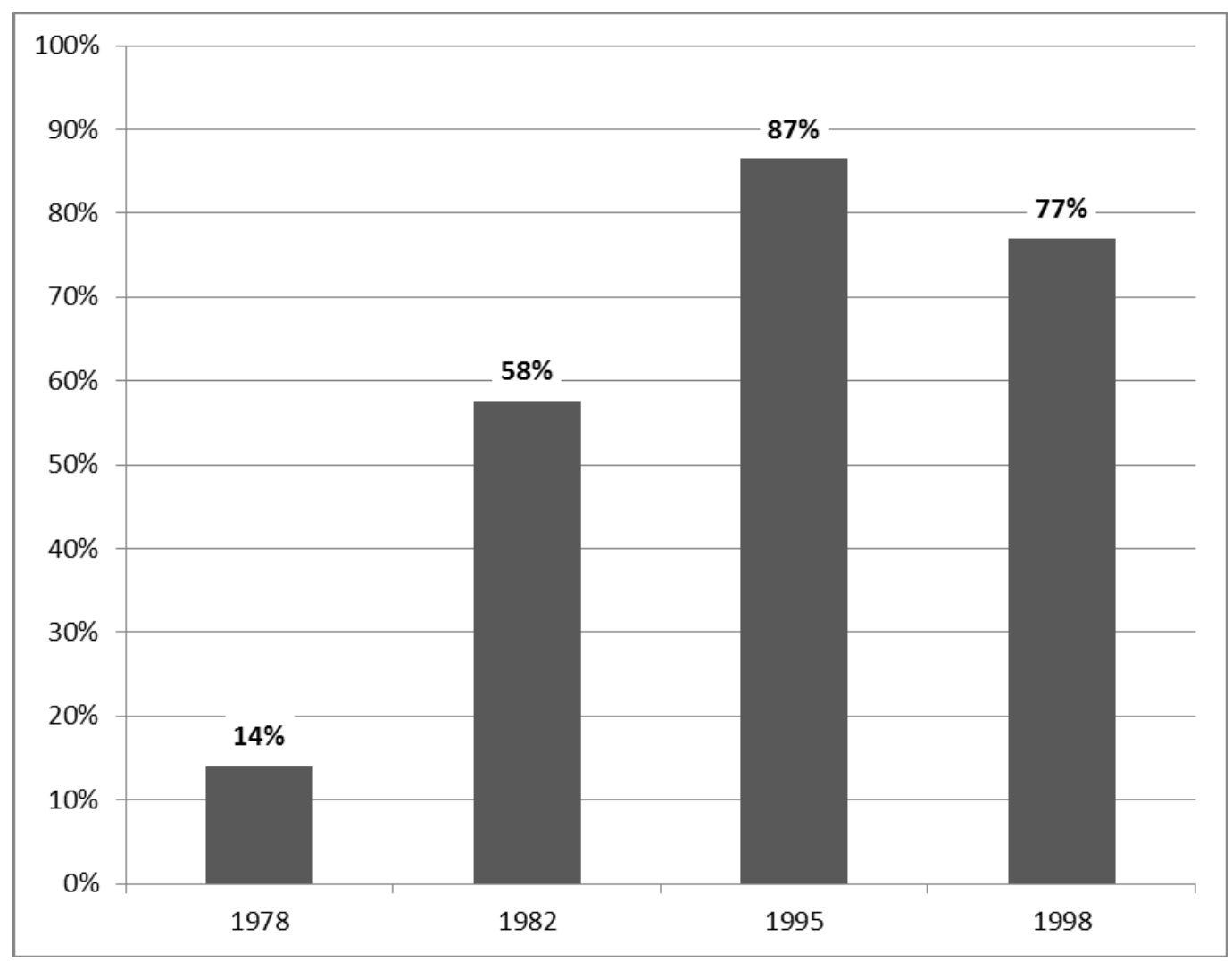

Figure 11: Percentage of firms using inflation adjusted cash flows

\section{Re-investment rate and use of modified internal rate of return (MIRR)}

Only $17 \%$ of respondents in Andrews and Butler (1986) made an assumption regarding reinvestment rates of return. The DCF methods make an implicit assumption that cash flows generated by the project will be reinvested at either the cost of capital (NPV) or the internal rate of return (IRR). It is more accurate to set a reinvestment rate or to assume the cost of capital as the re-investment rate.

The modified internal rate of return (MIRR) approach was devised to deal with a major drawback of IRR, namely that IRR may result in suboptimum project rankings and inaccurate promised returns. This is due to the fact that IRR assumes that project cash flows are reinvested at a project's IRR (see Kellerher \& MacCormack, 2004). MIRR requires one to set a specific reinvestment rate for intermediate project cash flows, which is normally set at the cost of capital of the firm.

MIRR is now included as a function within Excel, which facilitates the calculation of a project's MIRR. Yet the survey by Correia and Cramer (2008) found that only 7.5\% of South African companies used the MIRR to evaluate capital projects. This may reflect a lack of understanding by management of the reinvestment assumption implicit in the use of IRR and the consequences of using IRR on project returns and rankings. Therefore, in relation to the adoption of MIRR, capital budgeting practice has not kept pace with advances in theory. However, for some firms this may reflect the fact that companies have adopted NPV which is not subject to the drawbacks of using IRR. Burns and Walker (2009) report limited use of MIRR by large US firms.

\section{Choosing between mutually exclusive projects}

Only $31 \%$ of respondents in Andrews and Butler (1986) use incremental cash flows to evaluate mutually exclusive projects. Most $(54,9 \%)$ of the respondents select the alternative with the best rating in terms of the method that they normally use.

Du Toit and Pienaar (2005) investigate this issue in depth and report that IRR is one of the most important primary methods used to rank mutually exclusive projects, with $35 \%$ of firms using IRR and 35\% of firms using NPV. The study found that $11 \%$ of firms use discounted payback and few firms use the Profitability index. Further, respondents were asked a hypothetical question about ranking two mutually exclusive projects, where one project has a higher NPV but a lower IRR and a shorter payback than the other project. Interestingly, $64 \%$ of firms chose the project with the higher IRR, a decision which is not aligned with finance theory.

Internationally, surveys do not address the specific issue of ranking mutually exclusive projects, but Hogabaom and Shook (2004) in a survey of the capital budgeting practices in the U.S. forest products industry found that IRR was the most important method used to rank mutually exclusive projects and IRR was the most important method used in the case of capital rationing. Again, these practices are not aligned with finance theory.

\section{Income tax}

Financial theory indicates that firms should evaluate projects on the basis of after-tax cash flows. Income tax would impact on the operating cash flows and firms need to take into account tax incentives such as depreciation allowances 
available to encourage investment in plant and machinery and factory buildings. The cost of capital is also based on the after tax cost of financing.

Therefore, it is surprising that some surveys found that there are a sizable number of firms which are not adjusting cash flows for income tax. Lambrechts (1976) found that $50 \%$ of the firms which employed the ARR method did not take tax into account. Unfortunately, he does not indicate the percentages for firms employing DCF techniques which do not adjust cash flows for taxation. Reeve (1981) does not indicate whether firms have adjusted cash flows for income tax and Andrews and Butler (1986), as well as Parry and Firer (1990) do not address this issue. The survey by Coltman (1995) found that $70,8 \%$ of companies evaluate projects on an after tax basis. This means that a sizable number of firms $(29,2 \%)$ do not take tax into account in evaluating capital projects.

Kester et al. (1999) reported in his survey of capital budgeting practices within the Asia-Pacific region that although the majority of respondents indicated that cash flows are determined after tax, a sizable minority of firms in Hong Kong (41\%), the Philippines (40\%) and Singapore $(42 \%)$ evaluated future cash flows before tax. In Australia, $27 \%$ of firms and $29 \%$ of firms in Malaysia evaluate cash flows before tax whilst in Indonesia only $7 \%$ of firms evaluate future project cash flows before tax. Whilst firms may decide to employ a before tax discount rate to discount before tax cash flows, further research is required to determine the motivations of firms. Otherwise, there are a minority of firms who are not including tax in the evaluation of capital projects. This is further accentuated if firms are subject to depreciation tax shields. The use of APV is limited as this may have pointed to the separate valuation of tax shields.

Danielson and Scott (2006) in their survey of the capital budgeting practices of small firms in the USA found that $26 \%$ of firms did not assess or evaluate the tax consequences of investment decisions.

\section{The performance of companies who have adopted DCF methods}

The adoption of sophisticated capital budgeting techniques should result in superior firm performance and a number of empirical studies have tested the relationship between capital budgeting practices and firm performance. Klammer (1973) tested the relationship between the rate of return on investment and the use of sophisticated capital budgeting techniques, but found no significant relationship between these two variables.

Haka, Gordon and Pinches (1985) used market returns as the measure of performance and tested the adoption of sophisticated techniques in relation to firm performance as measured by changes in share prices. Sample companies were divided into an experimental group, which adopted sophisticated techniques and a control group which employed naive methods to evaluate projects. The study found that the adoption of sophisticated techniques did not, per se, result in superior firm performance. However, firms that adopted DCF techniques were on average experiencing declining returns in relation to the returns achieved by the control group, prior to the adoption of such sophisticated techniques and were able to show positive short run effects after these firms adopted DCF techniques. The adoption of sophisticated techniques may therefore simply reflect a response to economic stress and the adoption of these methods enabled the firms to at least match the performance of the companies in the control group.

Kim and Farragher (1982) found a significant relationship between earnings performance and capital budgeting practices. Earnings performance was measured by after-tax operating cash flows in relation to operating assets. The variable, "sophisticated techniques" was defined more comprehensively than in other studies by requiring adherence to nine criteria and therefore measured the level of sophistication of capital budgeting practices by additional factors than the simple adoption by firms of sophisticated techniques.

For South Africa, Andrews and Butler (1986) state that firms that are sophisticated in their approach to capital investment, as measured by specified criteria, were found to be more profitable and experienced faster growth rates. The adherence to the concept of the maximisation of shareholder wealth is more closely met by the use of DCF techniques and this represented the primary indicator of the level of sophistication of firms in undertaking project evaluations.

Coltman (1995) employs Cumulative Abnormal Returns to compare the results of DCF dominant firms relative to the performance of Non-DCF dominant firms. Responding firms which employed DCF methods for more than $75 \%$ of the time were classified as DCF dominant firms and firms which did not employ DCF methods for more than $75 \%$ of the time were classified as Non-DCF dominant firms. Market returns for each firm were compared to their respective sector returns to calculate annual abnormal returns. These annual abnormal returns were then accumulated to obtain the cumulative abnormal return (CAR) for each period. Data on share returns and sector returns were obtained from the Bureau of Financial Analysis (BFA) network. The CARs of DCF-dominant firms and Non-DCF dominant firms is plotted in Figure 12.

Coltman (1995) states that based on the respective CARs of the DCF dominant firms relative to the CARs of the NonDCF dominant firms, the adoption of sophisticated techniques did not result in superior firm performance. In fact, the CAR plots indicate that the Non-DCF firms outperformed the firms which employed DCF methods to evaluate projects. However, Coltman found that in the last two years of his study, DCF firms strongly outperformed non-DCF firms.

The evidence in this regard is inconsistent. International surveys have reported no evidence of superior firm performance, yet the adoption of DCF methods may reflect a response to firms experiencing economic stress. For South Africa, Coltman found evidence that the adoption of sophisticated capital budgeting techniques over the whole period under review did not result in superior firm 
performance, although in the latter years, DCF firms did outperform non-DCF firms. Further research is required in this area in respect to the methodology employed, the selection of sector indices and firm selection as well as defining what represents the use of sophisticated capital budgeting techniques.

\section{Capital budgeting decisions and shareholder wealth}

Is capital budgeting consistent with the maximisation of shareholder wealth in South Africa? Bhana (2008) analysed 378 capital expenditure decisions in the period 1995 to 2004 and found significant positive excess returns for shareholders in the period around such capital expenditure announcements, particularly for focused firms. This may indicate that capital budgeting decisions add value to shareholders.

\section{Real options}

A major development in finance theory is to include embedded real options and project flexibility in the valuation of capital projects. NPV analysis may be enhanced by the inclusion and analysis of real options in the evaluation of capital projects. Yet, in the USA, Block (2007) surveyed the Fortune 1000 firms and found that only $14 \%$ of responding companies used real option analysis to enhance the results arising from the traditional NPV and IRR analysis of capital projects. However, the survey also found that $44 \%$ of non-users in the USA indicated they would consider the use of real option analysis in the future.

Kester et al. (1999), found for the USA, UK, Netherlands, Germany and particularly France, that from 26\% to 53\% of firms incorporate real options when evaluating projects. This may indicate a qualitative analysis of project flexibility rather than applying a formal real option valuation methodology. Ryan and Ryan (2002) found very limited use of real option analysis by Fortune 1000 companies with $89 \%$ of companies never or rarely ever using real option analysis. In the UK, Alkaraan and Northcott (2006) reported that only $3.6 \%$ of respondents regarded the application of the real options approach as important and only another $16.9 \%$ of companies regarded this approach to be of average importance. The limited use of formal real option analysis in the UK is confirmed by MacDougall and Pike (2003).

Correia and Cramer (2008) found that only 10,7\% of companies in South Africa used real option analysis. In the section on risk analysis, Correia and Cramer (2008) found that $14 \%$ of South African companies evaluated abandonment and expansion options. Further, the survey also found that South African companies made limited use of Monte Carlo simulation, decision trees and APV, techniques which may be linked to real option analysis.

Mokenela (2006) surveyed the top 40 listed firms on the JSE Securities Exchange and found that only 9\% of responding firms used real options in project evaluation. This result is in line with the results of Correia and Cramer (2008). However, Mokenela (2006) also reported that managers recognise the value of project flexibility even if they may not quantify the value of project flexibility in a real option valuation model setting.

The reasons given for the non-use of real options in the USA relates to the lack of top management support, the level of complexity and the view that the use of real options encouraged excessive risk taking. Management may view the use of real option analysis to ensure project acceptance when NPV or IRR analysis may indicate that projects should not be accepted. Yet the use of IRR may have a similar impact if the implied reinvestment rate assumption is not likely to be attained in the future.

The existence of real operating options means that the use of the NPV technique may be questionable unless specific provision is made for the value of real operating options available to firms undertaking capital projects. Therefore, in a broader context, we cannot simply praise the ascendancy of NPV but need to take into account the value of real options. The existence of real options would impact on all the methods used to evaluate capital investments but will more closely align the concepts of strategic planning and capital budgeting.

\section{Further issues included in South African capital budgeting surveys}

Hall (2000) in his survey found that the most important $(66 \%)$ and most difficult stage $(46 \%)$ in the capital budgeting process was project definition and cash flow estimation. This is set out in Figure 13. In contrast, only $29 \%$ of companies found the financial analysis and project selection stage to be the most difficult and $26 \%$ found it to be the most important stage. The project implementation and project review stages were viewed by most companies to be relatively unimportant and not difficult although companies did regard project implementation to involve some risk. Project definition and cash flow estimation was also regarded as the most risky stage of the capital budgeting process.

The reason why Hall's results are relevant is that it clearly indicates that the most important and most difficult stage, project definition and cash flow estimation, is not reflected in many of the research surveys to date. Almost all the surveys have researched the financial analysis and project selection stage. These results are confirmed by Brijlal and Quesada (2008) for businesses in the Western Cape, who found that $56 \%$ of firms identified project definition to be the most important stage in capital budgeting, whilst only $26 \%$ of firms identified the analysis and selection phase to be the most important stage in capital budgeting. Only Gilbert (2005) investigates the capital budgeting process in greater detail in relation to the project identification and cash flow estimation phase, as well as the other phases, in a case study analysis of two firms. 


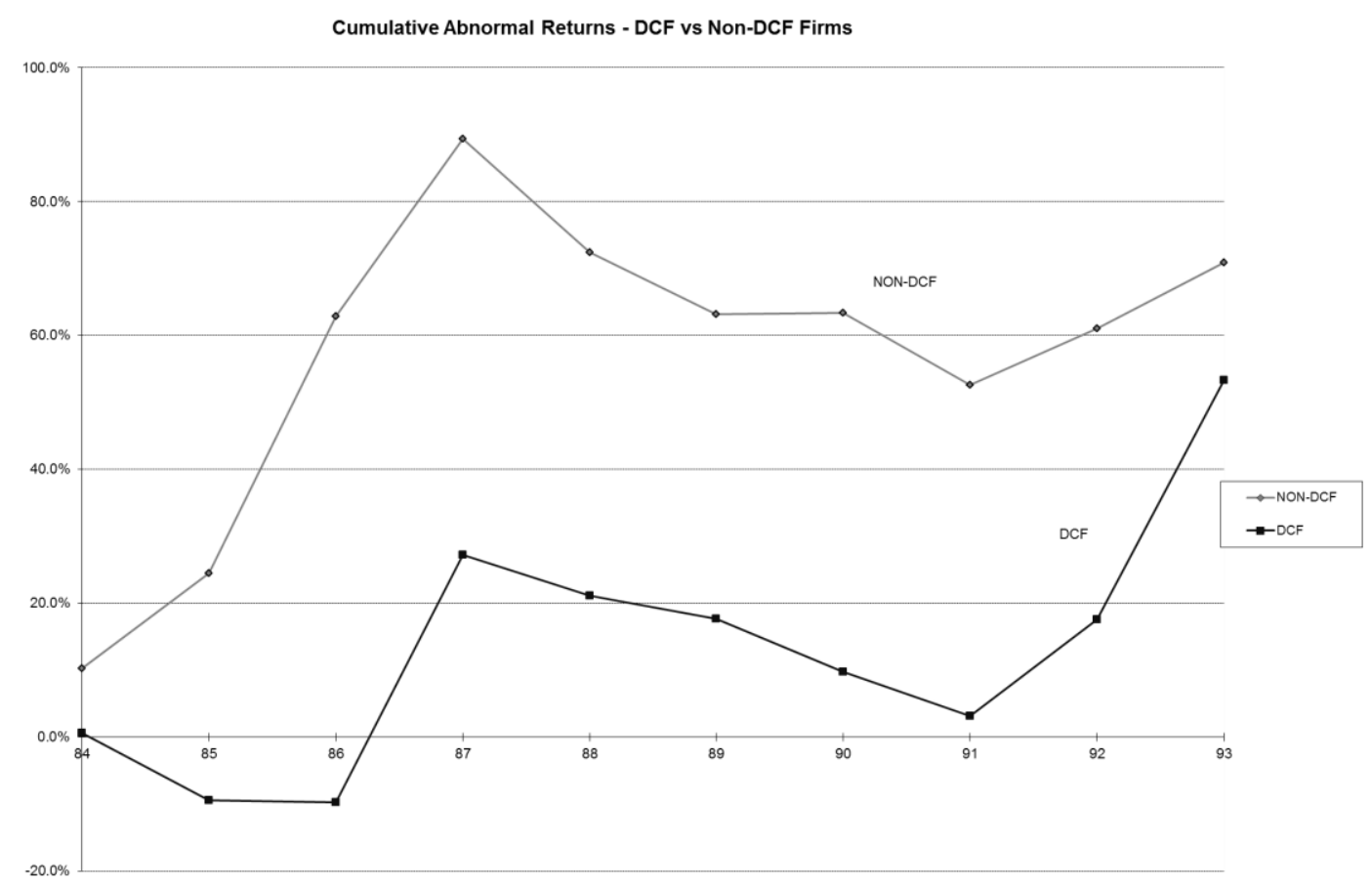

Figure 12: Cumulative abnormal returns - DCF vs Non-DCF firms

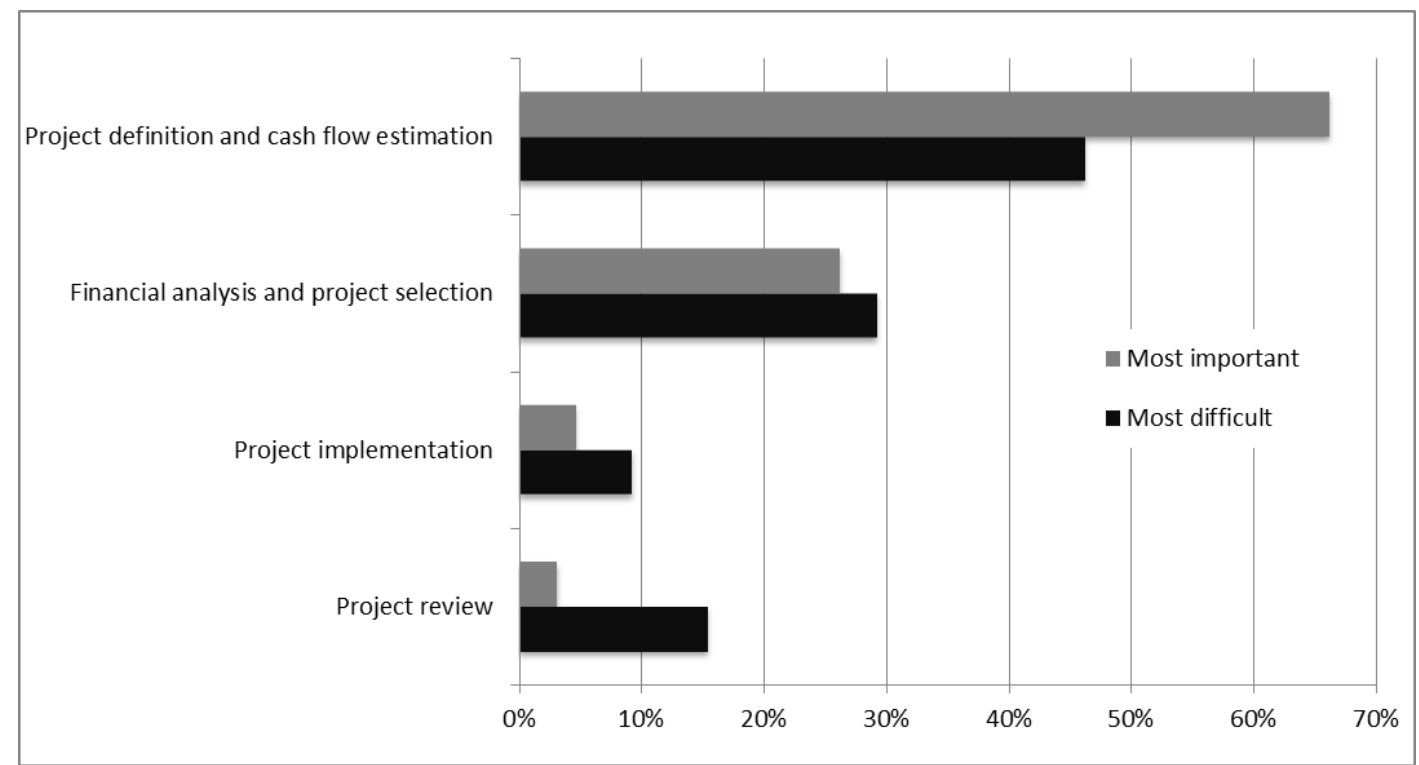

Figure 13: Most important and most difficult stages in capital budgeting

Future research needs to increasingly explore issues that arise in the project definition and cash flow estimation stage. Burns and Walker (2009) in their survey of capital budgeting surveys in the USA confirm that there has been too much focus in the survey literature on the selection stage and too little research has been undertaken on the other stages of the capital budgeting process.

\section{Conclusion}

Despite the limitations of comparing surveys in South Africa over time, it is clear that there has been significant growth in the use of DCF capital budgeting techniques, a trend which is consistent with financial theory. Practice is moving closer to theory and the gap between theory and practice in relation to the adoption of DCF capital budgeting methods by firms is no longer a major consideration for academic study. In particular, there has been a dramatic increase in the use of NPV over the last thirty years and there has been a fall in the use of Payback and the Accounting rate of return methods. Yet, IRR remains the primary method used in project evaluation despite the fact that finance theory states that there are major disadvantages in the use of IRR as compared to NPV.

In relation to project risk analysis, the most popular methods are sensitivity analysis and there has been a significant growth in the use of scenario analysis. There has been very little growth in the use of such methods as Monte Carlo simulation and decision tree analysis over the last 20 years. Although firms undertake risk analysis of projects, most firms do not use risk adjusted discount rates and may use the discount rate for the firm to discount expected future cash 
flows. Most firms tend to use a combination of capital budgeting methods to evaluate projects.

The survey literature indicates that larger firms tend to use DCF methods such as IRR and NPV and small firms make greater use of Payback and ROI (ARR). Most surveys indicate a preference for NPV by larger firms but there is also survey evidence that large companies prefer IRR. In the mining sector most companies use NPV. In South Africa close to nine out of ten companies undertake post completion audits. However, further research is required to understand the nature and impact of such post completion audits and the forecasting accuracy in relation to revenues and costs.

In South Africa, unlike the USA, most firms discount inflation-adjusted cash flows at the cost of capital. The discounting of inflation-adjusted cash flows at a nominal discount rate is in line with finance theory.

There is limited use by South African companies of such methods as MIRR, EVA, APV and real option analysis. Further, the ranking of mutually exclusive projects by South African companies is not aligned with finance theory. However, firms seem to recognise, if not quantifiably value, project flexibility. In line with finance theory, most South African firms evaluate projects on the basis of after-tax cash flows.

The evidence presented is inconclusive in respect to the relative performance of DCF firms and non-DCF firms, yet DCF dominant firms do not appear to outperform non-DCF firms. Further research needs to be undertaken to measure the relative performance of companies that have adopted DCF methods as compared to companies which use naive methods to evaluate capital projects.

Although a number of capital budgeting practices are increasingly in line with finance theory, there remain unexplained differences between practice and theory relation to such issues as the continuing importance of IRR, the low use of advanced methods such as Monte Carlo simulation, MIRR and risk adjusted discount rates. Further, the survey literature has placed too much emphasis on the selection phase of the capital investment and future research should increasingly focus on the identification and control phases of capital investment.

\section{References}

Alkraan, F. \& Northcott, D. 2006. 'Strategic capital investment decision-making: A role for emergent analysis tools? A study of practice in large UK manufacturing companies', British Accounting Review, 38:149-173.

Andrews, G.S. \& Butler, F. 1986. 'Criteria for major investment decisions', The Investment Analysts Journal, 27:31-37.

Arnold, G.C. \& Hatzopoulos, P.D. 2000. 'The theorypractice gap in capital budgeting: evidence from the United Kingdom', Journal of Business Finance and Accounting, 27(5\&6):603-626.
Bhana, N. 2008. 'The market reaction to capital expenditure announcements', The Investment Analysts Journal, 68: 5364.

Blazouske, J.D., Carlin, I. \& Kim, S.H. 1988. 'Current capital budgeting practices in Canada', CMA Magazine, 62(2): 51-54.

Block, S. 2007. 'Are 'real options' actually used in the real world?', The Engineering Economist, 52(3): 255-268.

Brijlal, P. \& Quesada, L. 2008. 'The use of capital budgeting techniques in businesses: A perspective from the Western Cape'. Conference Proceedings. $21^{\text {st }}$ Australasian Finance and Banking Conference, Australian School of Business, The University of New South Wales, December, Sydney, pp.2136-2152.

Burns, R.M. \& Walker, J. 2009. 'Capital budgeting surveys - the future is now', Journal of Applied Finance, 1\&2: 7890 .

Brounen, D., De Jong, A. \& Koedijk, K. 2004. 'Corporate finance in Europe: Confronting theory with practice', Financial Management, 33(4): 71-101.

Coltman, G. 1995. 'An analysis of capital budgeting techniques and their impact on shareholder wealth' B.Com (Hons) unpublished technical report, University of Cape Town.

Copeland, T. \& Antikarov, V. 2001. Real options: A practitioner's guide. New York: Texere LLC.

Copeland, T. \& Keenan, P. 1998. 'Making real options real', The McKinsey Quarterly, 3: 128-141.

Correia, C. \& Cramer, P. 2008. 'An analysis of cost of capital, capital structure and capital budgeting practices: A survey of South African listed companies', Meditari Accountancy Research, 16(2): 31-52.

Correia, C., Flynn, D., Uliana. E. \& Wormald, M. 2007. Financial management. 6th Edition. Cape Town: Juta.

Correia, C. \& Uliana, E. 2004. 'Market segmentation and the cost of equity of companies listed on the Johannesburg Stock Exchange', South African Journal of Accounting Research, 18(1): 65-86.

Danielson, M.G. \& Scott, J.A. 2006. 'The capital budgeting decisions of small businesses', Journal of Applied Finance, Fall/Winter: 45-56.

Dixit, A.K. \& Pindyk, R.S. 1995. 'The options approach to capital investment', Harvard Business Review, May/June: 105-115.

Du Toit, M.J. \& Pienaar, A. 2005. 'A review of the capital budgeting behaviour of large South African firms', Meditari Accountancy Research, 13(1): 19-27. 
Freeman, M. \& Hobbes, G. 1991. 'Capital budgeting: Theory versus practice', Australian Accountant, 61: 36-41.

Gilbert, E. 2003. 'Do managers of South African manufacturing firms make optimal capital investment decisions?' South African Journal of Business Management, 34(2): 11-17.

Gilbert, E. 2005. 'Capital budgeting: A case study analysis of the role of formal evaluation techniques in the decision making process', South African Journal of Accounting Research, 19(1): 19-36.

Gitman, L. J. \& Forrester, J. R. 1977. 'A survey of capital budgeting techniques used by major U.S. firms', Financial Management, 6: 66-71.

Graham, J.R. \& Harvey, C.R. 2001. 'The theory and practice of corporate finance: Evidence from the field', Journal of Financial Economics, 60: 187-243.

Haka, S. G. L. \& Pinches, G. 1985. 'Sophisticated capital budgeting selection techniques and firm performance', Accounting Review, 60(4): 651-669.

Hall, J.H. 2000. 'Investigating aspects of the capital budgeting process used in the evaluation of investment projects', South African Journal of Economic \& Management Sciences, 3(3): 353-368.

Hall, J.H. 2001. 'Risk analysis and evaluation of capital investment projects', South African Journal of Economic \& Management Sciences, 4(2): 398-368.

Hogaboam, L.S. \& Shook, S.R. 2004. 'Capital budgeting practices in the U.S. forest products industry: A reappraisal', Forest Products Journal, 54(12): 149-158.

Kellerher, J.C. \& MacCormack, J.J. 2004. 'Internal rate of return: a cautionary tale', McKinsey on Finance, Summer: $16-19$.

Kester, G., Chang, R., Echanis, E., Haikal, S., Isa, M., Skully, M., Kai-Chong, T. \& Chi-Jeng, W. 1999. 'Capital budgeting practices in the Asia-Pacific Region: Australia, Hong Kong, Indonesia, Malaysia, Philippines, and Singapore', Financial Practice and Education, 9(1): 25-33.

Kim, S.H. \& Farragher, E.J. 1982. 'An empirical study on the relationship between capital budgeting practices and earnings performance', Engineering Economist, Spring: 185-196.

Kim, S.H. \& Ulferts, G. 1996. 'A summary of multinational capital budgeting studies’, Managerial Finance, 22(1): 7585 .

Klammer, T. 1973. 'The association of capital budgeting techniques with firm performance', The Accounting Review, 48(2):353-364.
Lambrechts, I.J. 1976. 'The practice of capital investment decision-making in South Africa', The Investment Analysts Journal, 8:27-31.

MacDougall, S.L. \& Pike, R.H. 2003. 'Consider your options: Changes to strategic value during implementation of advanced manufacturing technology', Omega, 31(1):115 .

McKinsey \& Co. 2007. 'How companies spend their money: A McKinsey Global Survey’, McKinsey Quarterly, June.

McMahon, R. 1981. 'The determination and use of investment hurdle rates in capital budgeting: A survey of Australian practice', Accounting and Finance, 21(1): 15-25.

Mokenela, L. 2006. 'Managerial flexibility using ROV: A survey of top 40 JSE listed companies'. Unpublished M.Com thesis, University of Stellenbosch.

Parry, H.M.A. \& Firer, C. 1990. 'Capital budgeting under uncertainty: An empirical study', Investment Analysts Journal, 21(3): 52-58.

Pike, R. 1996. 'A longitudinal survey on capital budgeting practices', Journal of Business Finance \& Accounting, 23(1):79-92.

Pocock, A.S., Correia, C. \& Wormald, M. 1991. 'An analysis of the approaches used by industrial companies listed on the JSE to identify their cost of capital', South African Journal of Accounting Research (De Ratione), 5(1): 27-40.

Reeve, R. 1981. 'Business investment decisions under inflation: Some South African evidence', The Investment Analysts Journal, 18: 9-17.

Ryan, P.A. \& Ryan, G.P. 2002. 'Capital budgeting practices of the Fortune 1000: How have things changed?' Journal of Business and Management, 8(4): 355-364.

Shao, L.P., \& Shao, A.T. 1996. 'Risk analysis and capital budgeting techniques of U.S. multinational enterprises,' Managerial Finance, 22(1):41-57.

Soares, J.O., Countinho, M.C. \& Martins, C.V. 2007. 'Forecasting errors in capital budgeting: A multi-firm postaudit study', The Engineering Economist, 52:21-39.

Trigeorgis, L. 1993. 'Topics in real options and applications', Financial Management, 22(3):202-223.

Truong, G., Partington, G. \& Peat, M. 2008. 'Cost-of-capital estimation and capital-budgeting practice in Australia', Australian Journal of Management, 33(1):95-121.

Waweru, N.M., Hoque, Z. \& Uliana, E. 2005. 'A survey of management accounting practices in South Africa', International Journal of Accounting, Auditing and Performance Evaluation, 2(3): 226-263. 